\title{
LA PROYECCIÓN DE LA MAGNIFICENCIA DE LOS AUSTRIAS: BREVE HISTORIA DE UN PALACIO EFÍMERO CONVERTIDO EN MUSEO Y SEMBLANTE HISTORICISTA DE SU PASADO
}

\author{
Matteo Mancini \\ Universidad Complutense de Madrid
}

RESUMEN: El edificio que albergó el Salón de Reinos tuvo una importancia fundamental en la Historia del Arte española y más en general en la historia de la cultura del Siglo de Oro. Los enormes contrastes entre el valor arquitectónico del edificio y sus decoraciones plantean el punto de arranque de este estudio que quiere llegar a definir la capacidad que tuvieron los rasgos efímeros de aquel espacio palaciego de proyectar su horizonte mucho más allá de su época. Es ya a mediados del siglo XIX cuando vuelven a brotar las razones ideológicas de su naturaleza que se fraguaron en la (re)edificación de lo que se conoció como Museo del Ejército, donde las necesidades museísticas de la época se templaron bajo la ideología historicista de recuperación de un lugar emblemático para la monarquía española.

Palabras clave:: arte efímero, arquitectura, museología, Salón de Reinos, Museo del Ejército.

AbSTRACT: The building that housed the Salón de Reinos was very representative in Spanish art history and more generally in the History of Culture in the Golden Age. The huge contrast between the architectural value of the building and its decorations raise the starting point from this study that wants to define the ability of ephemeral traits had that space to project palatial horizon far beyond his time. It's already midnineteenth century when they return to sprout ideological reasons of his nature that were forged in the (re)construction of what became known as the Museo del Ejército, where musistic needs of the time were annealed under historicist ideology recovery of a landmark for the Spanish monarchy. 
Keywords: Ephemeral Art, Architecture, Museology, Hall of Realms, Army Museum.

$\mathrm{E}^{\mathrm{I}}$ conjunto palaciego del Buen Retiro [Fig. 1] ha sido objeto de numerosas investigaciones que, sobre todo, a lo largo del último medio siglo han logrado precisar la existencia de una singular tensión dialéctica entre el valor simbólico/representativo de alguno de sus aposentos frente a la modesta estructura arquitectónico-constructiva global. Dos aspectos que, sin embargo, están íntimamente ligados a la historia y recepción de este espacio siendo imprescindible comprender las motivaciones que determinaron el desarrollo de ambos. ${ }^{1}$ Por otro lado, en las fuentes contemporáneas a la edificación y en la mayoría de los estudios críticos actuales, podemos comprobar que, de hecho, la iniciativa arquitectónica tomada por el conde-duque de Olivares se había limitado a la edificación de un nuevo aposento palaciego que debía exaltar la figura política del monarca y de su dinastía por medio de las decoraciones palaciegas (cuadros, esculturas etc.), ${ }^{2}$ dejando los semblantes arquitectónicos relegados a un plano secundario y subordinados a los aspectos protocolarios, así; influyendo en reiterar la supuesta, y ya muy discutible y tópica, ${ }^{3}$ "austeridad» de la corte de los Austrias españoles.

De tal manera que, el Palacio del Buen Retiro [Fig. 2] no se edificó como un conjunto homogéneo bajo un proyecto arquitectónico previo, sino por medio de un proceso de ampliaciones y yuxtaposiciones progresivas que empezaron desde el pequeño aposento real anexo al Monasterio de los Jerónimos que gozaba de patrocinio real desde 1528 para la jura de lealtad de las cortes de Castilla al heredero al trono. Una circunstancia clave a la hora de entender las líneas propulsoras del proceso de ampliación en el que, evidentemente, la representación figurativa y ceremonial de conceptos como magnificencia y decoro tuvieron que tener un papel central, determinando, a lo largo del pro-

1. En palabras de Jonathan Brown nos encontramos ante «una historia caprichosa, más hija del impulso que de la premeditación. En muchos Aspectos fue solo una cáscara destinada a contender un magnífico despliegue de las artes. De exterior más bien soso y prácticamente ajeno a las fórmulas arquitectónicas del Renacimiento italiano, el Retiro no fue lugar de residencia habitual del monarca y su corte»; J. BROWN, «El Palacio del Buen Retiro: un teatro de las Artes» en El Palacio del Rey Planeta. Felipe IV y el Buen Retiro, Cat. Exp., (A. Úbeda De los Coвos ed.), Museo Nacional del Pardo, Madrid, 2005, pp. 66-67.

2. Un concepto desarrollado por F. Marías, Pintura de Historia, imágenes políticas. Repensando el Salón de Reinos, Madrid, 2012.

3. Hacemos referencia a los términos cuantitativos de los objetos de lujo presentes en los Inventarios de Carlos Vy de su Familia (F. CHECA dir.) Madrid, 2010 y por los Libros de Entrega de El Escorial (F. CHECA dir.), en prensa. 


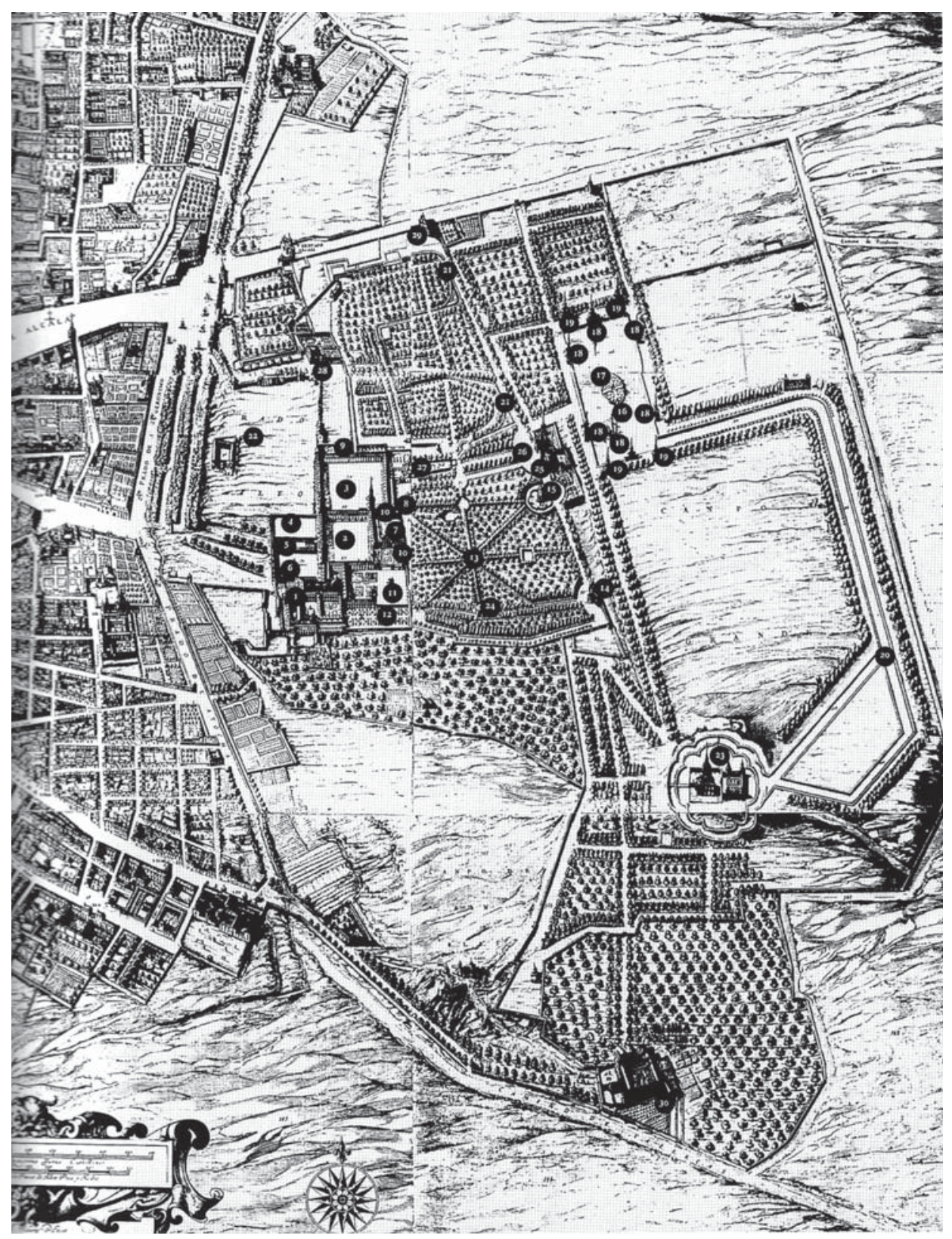

Fig. 1. Plano de Texeira de la ciudad de Madrid de 1656, detalle de la zona del Palacio del Buen Retiro, BNM 
ceso edilicio ${ }^{4}$ rasgos más propios del arte efímero ${ }^{5}$ que de la gran arquitectura barroca,${ }^{6}$ hasta el punto de convertir el edificio en una estructura alternativa a los aposentos reales de recreo, ${ }^{7}$ típicos del ritmo estacional de los Austrias, ${ }^{8}$ aunque sin tener una temporada específica y funcional para su uso. ${ }^{9}$

Las obras se dieron por acabadas con la inauguración de la Plaza Principal que, sin embargo, se quedó pequeña casi desde su origen, obligando a la construcción de otra, conocida como Plaza Grande. La separación entre estas dos plazas se plasmaba en la crujía que durante aproximadamente los últimos

4. Un proceso que empezó por iniciativa del conde-duque posteriormente al nacimiento del príncipe Baltasar Carlos, hijo de Felipe IV e Isabel de Borbón, el 17 de octubre de 1629 y cuyo plazo finalizaba el 7 de marzo de 1632, fecha prevista para la ceremonia del juramento. Por estas razones era necesario no dejarse escapar la ocasión de la jura. Olivares actuó con rapidez metiendo al frente de las obras Giovan Battista Crescenzi, ayudado por Alonso Carbonel, ambos personajes cercanos a su entorno y de mucha más confianza que el arquitecto de corte Juan Gómez de Mora. La rapidez constructiva fue la característica principal de estas obras edilicias en las que se privilegiaron los objetivos estratégicos de Olivares frente a la solidez constructiva. Una circunstancia que marcó el destino de todo el conjunto para los siglos siguientes, como tendremos ocasión de comprobar a lo largo de este estudio. Olivares pudo contar con dos enormes ventajas en este sentido: la conocida austeridad edilicia de los edificios de los Austrias y la distribución modular de aquellos mismos edificios; cf. C. Blasco Rodríguez, El Palacio del Buen Retiro de Madrid. Un proyecto hacia el pasado, Madrid, 2001, p. 116.

5. Una circunstancia que permitió construir los diferentes aposentos del Buen Retiro como módulos independientes y cuya edificación podía yuxtaponerse a las estructuras anteriores sin problemas, casi como si te tratara de quintas escenográficas. El primer paso fue la ampliación de la crujía anexa al claustro de los Jerónimos en 1632. En enero del año siguiente se realizó la edificación del llamado Cuarto Real, que comprendía el Cuarto del Príncipe o Galería de Toledo. Podemos considerar estas obras aún en el marco de la simple ampliación del aposento real en el Monasterio de los Jerónimos, sin embargo, en la primavera de 1633 es cuando se dispara el proceso edilicio, como confirman los despachos que Bernardo Monanni, secretario de la embajada del Gran Duque de Toscana, remitía a Florencia. En ellos se hacía especial hincapié, por un lado en el gran número de obreros y albañiles que estaban trabajando en el Retiro, $y$, por otro, en el continuo transformarse del proyecto inicial según un criterio expansivo de los espacios palaciegos a expensas de la calidad de los mismos; Carta del 9 de septiembre de 1634, Archivo di Stato Mediceo, Florencia, citado en J. Brown, J. Elliott, Un palacio para el Rey. El Buen Retiro y la corte de Felipe IV, Madrid, 2003, pp. 86-87.

6. Confirmando de esta manera que la magnificencia arquitectónica y la solidez constructiva no constituyeron las prioridades de este proyecto edilicio «El edificio resulta proporcionado a la grandeza del lugar, pero su arquitectura en general es desabrida por no haber atendido a los consejos de los arquitectos, aunque eran italianos y eminentes. Solo les preocupó la comodidad el acabarlo rápidamente, sin importarles las majestad y firmeza de la obras, cualidades que deben de ser tenidas en cuentas en las obras reales. Así el edificio ha quedado demasiado bajo, las ventanas mezquinas, desnudas y vulgares, las habitaciones demasiado largas y estrechas. Y porque tan solo prepararon los terrenos para lo que se ha construido apenas podrán ampliarlo en el futuro, aunque incluso ahora cada día cambian los proyecto y los engrandece»; Ibidem.

7. El Palacio del Buen Retiro, en los planes del conde-duque, iba a convertirse en una válida alternativa -de ocio y recreo- al Palacio de Aranjuez y al Monasterio de San Lorenzo de El Escorial. Como aquellos tenía cerca una fundación real, el Monasterio de los Jerónimos, pudiendo contar, sin embargo, con una extraordinaria cercanía al Alcázar. Circunstancia que permitía por un lado reducir los costes de mantenimiento y traslado de la Corte, y por otro lado ofrecía un mayor control político de la monarquía por parte del propio conde-duque; véase A. Bustamante García, «El palacio del Escorial», en Palacios Reales de España, D. Rodríguez Ruiz dir., Madrid 1996, pp. 67-84; V. Tovar Martín «El Palacio de El Pardo», en Ibídem, pp. 85-106; J. L. SANCHO GASPAR «El Palacio de Aranjuez» en Ibídem, pp. 107-124.

8. J. L. SAncho, G. Martínez-Leiva, ¿Donde está el Rey? El ritmo estacional de la corte española y la decoración de los Reales Sitios (1650-1700), en Cortes del Barroco. De Bernini y Velázquez a Luca Giordano, Cat. Exp. (F. CheCA com.), Madrid, 2003, pp. 85-99.

9. J. M. Morán Turina, F. Checa Cremades, las casas del Rey. Casas de Campo, Cazaderos y Jardines. Siglos XVI-XVII, Madrid, 1996. 


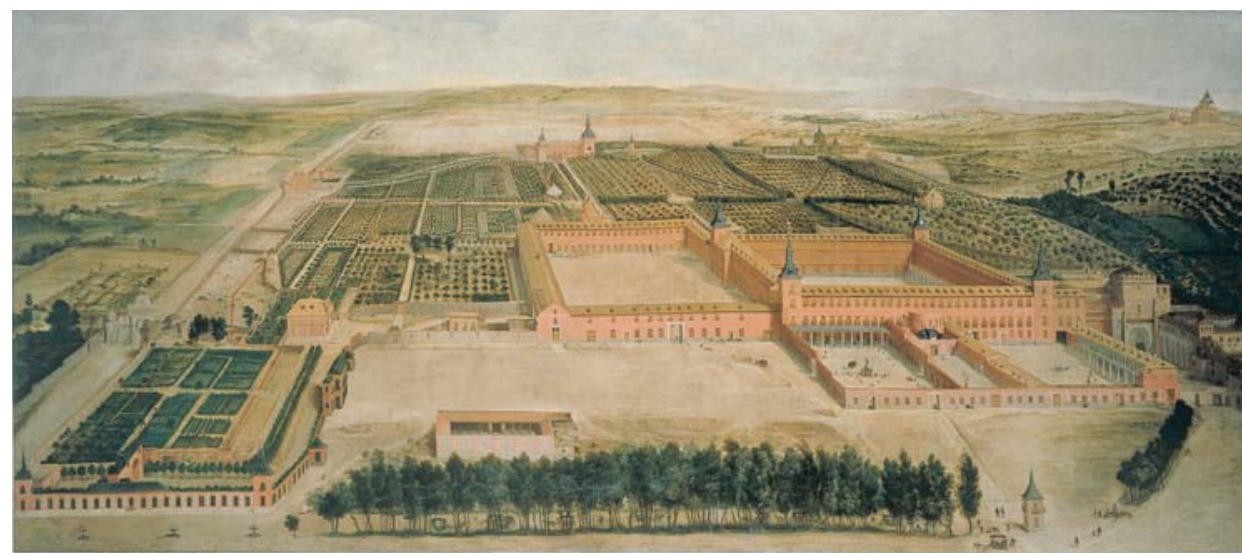

Fig. 2. Jusepe Leonardo, Vista del Palacio del Buen Retiro, Patrimonio Nacional, Madrid

cien años se ha conocido como sede del Museo del Ejército y anteriormente con diferentes apodos que hacían referencia a los elementos ideológicos y políticos de su decoración interior, ${ }^{10}$ es decir, el llamado Salón de Reinos [Fig. 3].

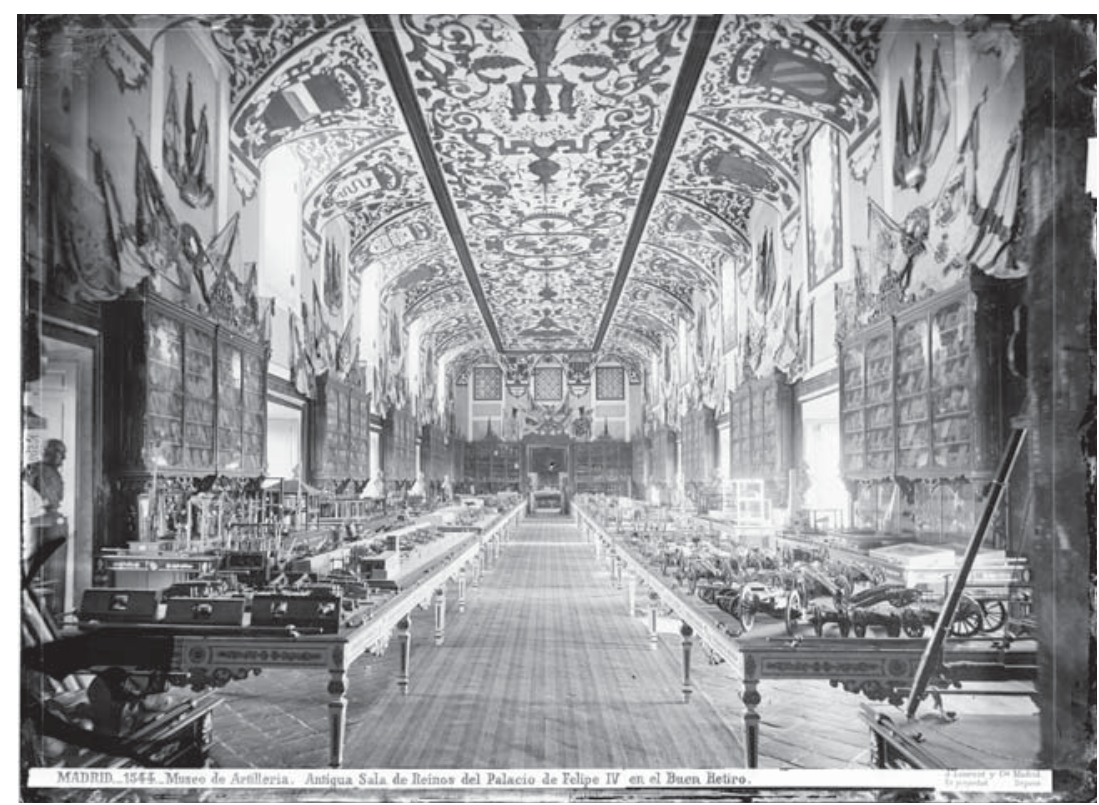

Fig. 3. Laurent, fotografía del Salón de Reinos, entre 1856 y 1880, Archivo Vernacci, 405, IPHE

10. Marías, F., Pintura de Historia, imágenes políticas, op. cit., pp. 32-68, aunque en opinión nuestra habría que renfocar algunos aspectos de la función alegórica de los personajes del tapiz de la Recuperación del Brasil, cf. M. MANCINI, «Iconografía y recepción de pintura veneciana en España» en Tras el centenario de Felipe IV, Jornadas de Iconografía y coleccionismo dedicadas al prof. A. E. Pérez Sánchez, J. M. PITA ANDRADE (dir.), Madrid, 2006, pp. 334-346. 
Este espacio palaciego era quizás el de mayor envergadura simbólica donde se celebraban, a través de un conjunto de pinturas de gran tamaño, las hazañas militares de Felipe IV y la gloria de la Monarquía española para poder albergar de esta manera, ya no la sala del trono, ajena a la tradición de los Austrias, sino la representación en cuerpo presente de la Majestad. Un espacio que la historiografía de la segunda mitad del siglo xx ha logrado restituir en su estructura esencial y que ${ }^{11}$ pese a las diferentes posturas críticas, reconoce cada vez con mayor seguridad la existencia de una balconada corrida. ${ }^{12}$ Elemento arquitectónico que desapareció definitivamente en la reforma de 1880, cuando, evidentemente, se había procedido a una transformación sustancial de las razones ideológicas, políticas y funcionales de los antiguos espacios palaciegos en favor de un marco museístico, como veremos más adelante. Un proceso que, sin embargo, ya había empezado a tomar forma hacia mediados del siglo XVIII de la mano de Santiago Bonavia [Fig. 4] y que se truncó por la inauguración del Palacio Real Nuevo $;^{13}$ relegando el Buen Retiro a un espacio

11. E. Tormo y Monzó, «Velázquez, el Salón de Reinos del Buen Retiro y el Poeta del Palacio y el Pintor» en Boletín de la Sociedad Española de Excursiones, n. ${ }^{\circ}$ XIX (1911), pp. 24-44, 85-111, 191-217, $274-$ 395, n. ${ }^{\circ}$ Xx (1912) pp. 60-63; M. ${ }^{a}$ L. CATURLA, «Cartas de pago de los doce cuadros de batallas para el Salón de Reinos del Buen Retiro» en Archivo Español de Arte n. 33 (1960), pp. 333-355; M. Morán, «Pues es más Alejandro que tu Apeles» en El Palacio del Buen Retiro y el Nuevo Museo del Prado, Madrid, 2000, pp. 63-87.

12. Una labor de aproximación científica que ha desembocado en la reciente propuesta de José Álvarez Lopera que tiene el mérito de definir con extrema claridad la distribución de los diferentes salones y de sus elementos arquitectónicos fundamentales, como es por ejemplo la identificación en los dos testeros del Salón de Reinos la presencia de unas pequeñas puertas laterales y su relación con las pinturas allí expuestas. La función de aquellas puertecillas podía ser de dar acceso a la balconada corrida, presente en los tres salones de la planta principal del edificio. Dicha balconada se interrumpía a la altura del trono, por lógicas razones de etiqueta. De todas formas, de la existencia de esta galería corrida existen numerosas referencias en fuentes literarias y en algunas de ellas se aprecian hasta descripciones pormenorizadas de la misma, como es el caso de Gallegos que habla de «frisos eminentes/ de uno y otro balcón»; J. Brown, J. ELLIOTT, Un palacio para el Rey. El Buen Retiro y la corte de Felipe IV, op. cit., pp. 214-215. Fulvio Testi recuerda haberse sentado en ella, "acomodándose en unos bancos de madera»; Robert Bargave cita «una noble balconada todo en derredor»; mientras Baccio del Bianco en 1656 ofrece una descripción pormenorizada del conjunto deteniéndose en las dimensiones de la sala, en las decoraciones tanto de las paredes como del techo, en las características de la galería corrida y en la calidad de las pinturas. Un conjunto de referencias literarias y documentales que finalmente se encuentran refrendadas por la documentación relacionada con los gastos de un festejo celebrado en 1696, cuando se compraron velas para las «cornucopias del corredor», Unos espacios en los que, independientemente si allí se representara la Majestad de Felipe IV o festejos de diferentes índole, se planteaba un recorrido de oeste a este según un precisa lógica que identificaba el monarca español con una divinidad solar. En síntesis, y pese a las diferentes denominaciones que a lo largo de los siglos XVII y XVIII recibieron los tres salones, podemos afirmar que la planta principal del edificio estaba constituida por tres salones contiguos. El mayor de ellos era el propio Salón de Reinos, cuyas dimensiones eran aproximadamente el doble que el de los otros dos. El recorrido debía de ser de oeste a este, situando de tal manera el trono en correspondencia con el este. Algo perfectamente coherente con la «imagen solar» de Felipe IV y en perfecta concordancia con la disposición en el testero este del Salón de Reinos de los escudos de Castilla y León y de Aragón y con la decoración de arabescos dorados, que tenían una clara alusión a la emanación solar de la divinidad real; sobre estos temas y para las citas véase J. Álvarez lopera, «La reconstrucción del Salón de Reinos. Estado y replanteamiento de la cuestión», en $E l$ Palacio del Rey Planeta. Felipe IV y el Buen Retiro, op. cit., pp. 91-109, part. pp. 101-109. También la reciente aportación de F. Marías, Pintura de Historia, imágenes políticas, op. cit., pp. 20-29.

13. Una distribución que se mantiene sustancialmente inalterada en los proyecto de 1748 propuestos por Santiago Bonavia y cuya finalidad era la de hacer un Salón de Audiencias en otra parte del edificio. Sin embargo, en ambos dibujos de Bonavia aparecen, en el medio del Salón de Reinos, dos paredes con sus 
marginal destinado exclusivamente al ocio y la diversión, perdiendo de esta manera su anterior protagonismo, además de verse despojado de gran parte de las obras de arte que decoraban sus aposentos, tal y como sanciona Antonio Ponz. ${ }^{14}$ Una postura que revela, por parte del erudito español, los destellos de las razones ideológicas de mayor calado que le hacían apreciar el edificio: el Salón de Reinos merecía ser recordado en razón de su función política, dinástica e institucional y, sobre todo, por albergar los doce grandes cuadros que colgaban de sus paredes. No obstante, según Ponz, solo al $\mathrm{Ca}$ són del Buen Retiro y exclusivamente debido a los frescos de Lucas Jordán, hubiera merecido prestarle atención frente a una eventual obra de rehabilitación arquitectónica. Dicho de otra manera, el resto del palacio, incluida la crujía de la que nos estamos ocupando, no merecía consideración alguna por su valor arquitectónico pudiéndose prescindir de su arreglo. Al contrario, y pese a los estragos que procuró la invasión francesa, en los planes de reforma elaborado en época de Fernando VII, un monarca en busca de legitimidad, se indicaba en el Salón de Reinos uno de los espacios, junto con el Casón y

correspondientes huecos de paso. Circunstancia que plantearía de hecho una división del Salón de Reinos en tres espacios diferentes, algo de lo que, por otro lado no queda rastro documental ninguno, debiéndose descartar su efectiva realización. No obstante, a Bonavia y a Sabatini corresponden las remodelaciones más sustanciales en la distribución de los diferentes aposentos palaciegos, entre 1734 y 1764, cuando la corte entera se trasladó al complejo del Buen Retiro, debido al incendio del Alcázar. En este momento el palacio conoció un aparente segundo esplendor convirtiéndose en términos funcionales en el Palacio Real de Madrid y planteando su remodelación integral según los modelos franceses de la arquitectura representativa como proponían los diferentes proyecto de De Cotte que no se llegaron a desarrollar; prefiriéndose la edificación del Palacio Real Nuevo en el mismo espacio físico y simbólico que había ocupado el antiguo Alcázar de los Austrias; J. L. SAncho GaSpar, La arquitectura de los Sitios Reales, Madrid, 1995, pp. 642-647.

14. Lo refrenda la pormenorizada descripción que Antonio Ponz reserva al palacio en su Viaje a España destacando la explícita mención al mal estado de la construcción y al hecho de que su valor era más bien simbólico que arquitectónico, pese a la extraordinaria importancia de muchas de las obras de arte que todavía custodiaba. «Es el Palacio un cuadro grande regular con torres en las esquinas, que está confundido con otras obras añadidas después; pero aunque estuviese del todo descubierto, no habría en su arquitectura cosa que mereciese descripción particular, porque es fábrica hecha de priesa, de madera y ladrillo, al modo que comúnmente se construye en Madrid; ni en aquel tiempo era fácil emprender magnificencias; según la estrechez en que se hallaba el Real Erario. Aun los fundamentos son de aquella mala piedra, llamada de San Isidro; por cuya razón ha necesitado y necesita cada día de grandes y costos reparos. Entre las obras agregadas solamente merece considerarse la que llaman Casón, por el motivo que se dirá después. Esta Real habitación del Retiro, las demás destinadas para la familia y dependientes de S. M. tienen bastante comodidad, aunque le falta magnificencia. Los muebles que hoy existen en ella, se reducen particularmente a pinturas; y así se hablará de las principales, y que más consideración merecen, pues el hacerle memoria de ellas una por una sería fastidioso al más aficionado, respecto de que muchas son de un mérito muy trivial: otras de autores que entre nosotros se han dado a conocer y algunas copias. Estas pinturas se han mudado en repetidas ocasiones: porción de las mejores sirven hoy de adorno en el Real Palacio Nuevo [...]. Hay un salón, que llaman de los Reynos en donde se celebran las juntas de las ciudades de voto en cortes, y al rededor están pintadas las armas de los mismos Reynos y Provincias. El principal adorno de este salón consiste en doce cuadros muy grandes, que representan sucesos militares en que trabajaron a competencia diversos profesores. Si algún día se pensase en reedificar este Palacio del Buen Retiro, es de creer, que bien lejos de que este pedazo de arquitectura, que contiene la obra de Jordán, fuese comprendido en las demoliciones, se pensase cuidadosamente en su conservación, y en hacerle parte de cualquier proyecto; porque sería gran lastima destruirla, y difícil de suplir. Sin embargo por lo que los tiempos pueden traer consigo, sería empresa plausible grabar esta y otras excelentes obras de tantos autores». A. Ponz, Viaje de España, Madrid, 1793, Imprenta de la viuda de D. Joaquín Ibarra, vol. v, pp. 96 y 129-130. 


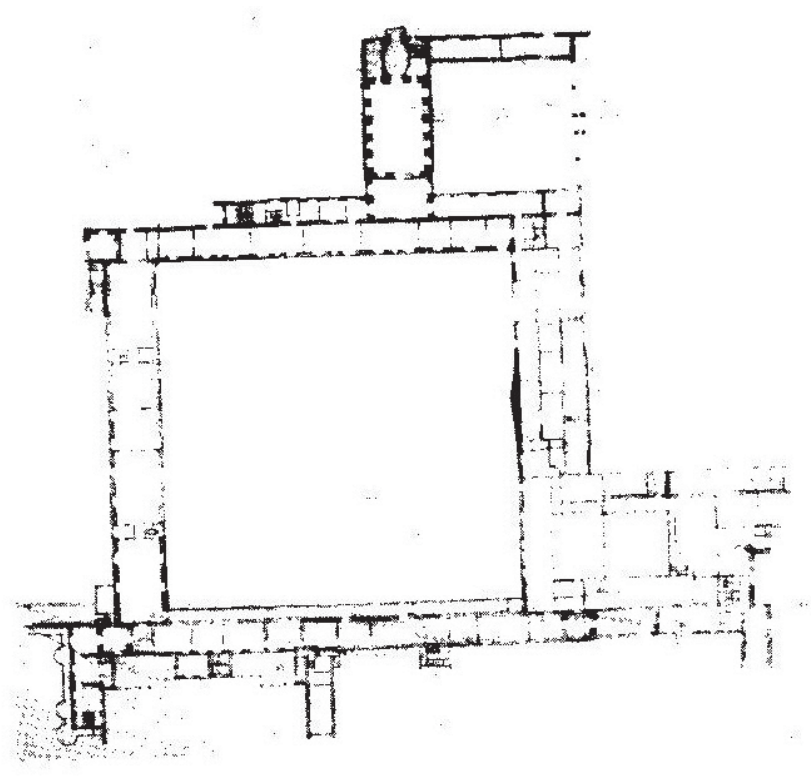

Fig. 4. Planos y alzados del proyecto de reforma de Isidro González Velázquez, 1820, AGP 4446

la iglesia de los Jerónimos, que «deben de conservarse» [Figs. 5-6], ${ }^{15}$ en tal sentido no es casual que se produzca una llamativa confusión indicando en la crujía del Salón de Reinos la «fachada de Palacio», es decir el eje de mayor envergadura y representatividad según la teoría arquitectónica de la Edad Moderna, cuando, en cambio, nos encontramos frente a lo que podríamos definir, más sencillamente, una quinta escenográfico-arquitectónica de una villa extra urbana, convertida en su interior en un fastuoso e imponente palacio barroco.

15. La invasión francesa y el hecho que en el complejo del Buen Retiro se instalaron las dependencias militares de los ocupantes, resultaron ser unas circunstancias decisivas, que decretaron la definitiva caída en desgracia del palacio junto el sistemático arrasamiento de algunos de los ejes urbanos previstos por la distribución y reformas llevadas al cabo por Carlos III .Un hecho que provocó, durante el reinado de Fernando VII, un intento de recuperación de aquellos espacios urbanos y la demolición de las obras de fortificación militar realizadas por los ocupantes franceses. Es en este marco que debemos interpretar los diferentes planos y proyectos de recuperación elaborados por Isidro González Velázquez y su entorno. Empezando por una planta esquemática del Palacio del Buen Retiro (AGP 551) donde se hace el punto de la situación de los edificios, de su estado y se proponen cuáles de ellos deben mantenerse y cuales pueden ser derribados. Un proyecto que encontramos refrendado por la planta y el alzado del Salón de Reinos trazada por el mismo González Velázquez hacia 1820 (AGP 4446), en la que no se aprecian diferencias sustanciales con lo planteado por las anteriores, sobre todo en lo relacionado con la distribución de los espacios y de las ventanas. En estos planos notamos, sin embargo, como la crujía del Salón de Reinos, debido con toda probabilidad al hecho de ser el espacio de mayor envergadura simbólica de todo el conjunto del Buen Retiro, llegue a ser definida como«Fachada de Palacio». Finalmente, es en el marco de la reforma proyectada por González Velázquez que tenemos que interpretar la remodelación de los espacios de la torre oeste que se destinaron a apartamentos y taller del pintor de cámara José Aparicio y que modificaron de forma definitiva aquella parte del edificio, que desde entonces ya no se correspondía a su estado original. 


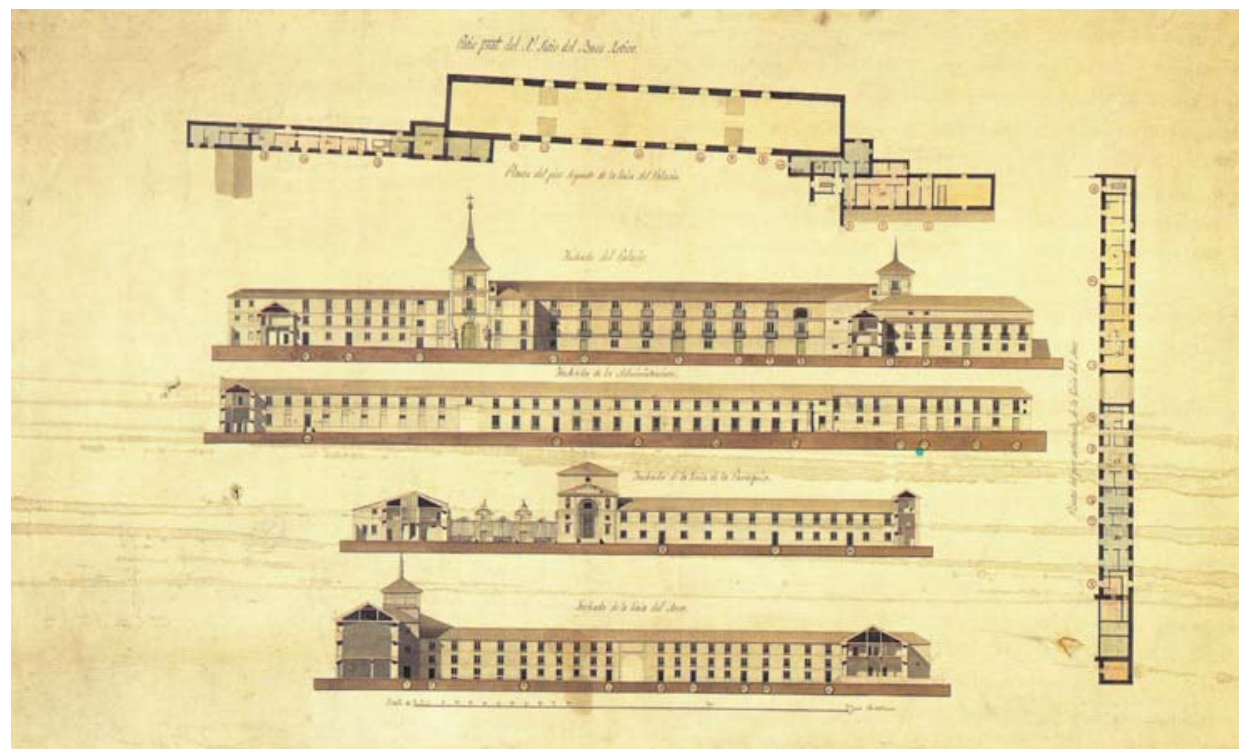

Fig. 5. Proyecto del remodelación del conjunto del Buen Retiro de Isidro González Velázquez, anterior a 1820, AGP 551

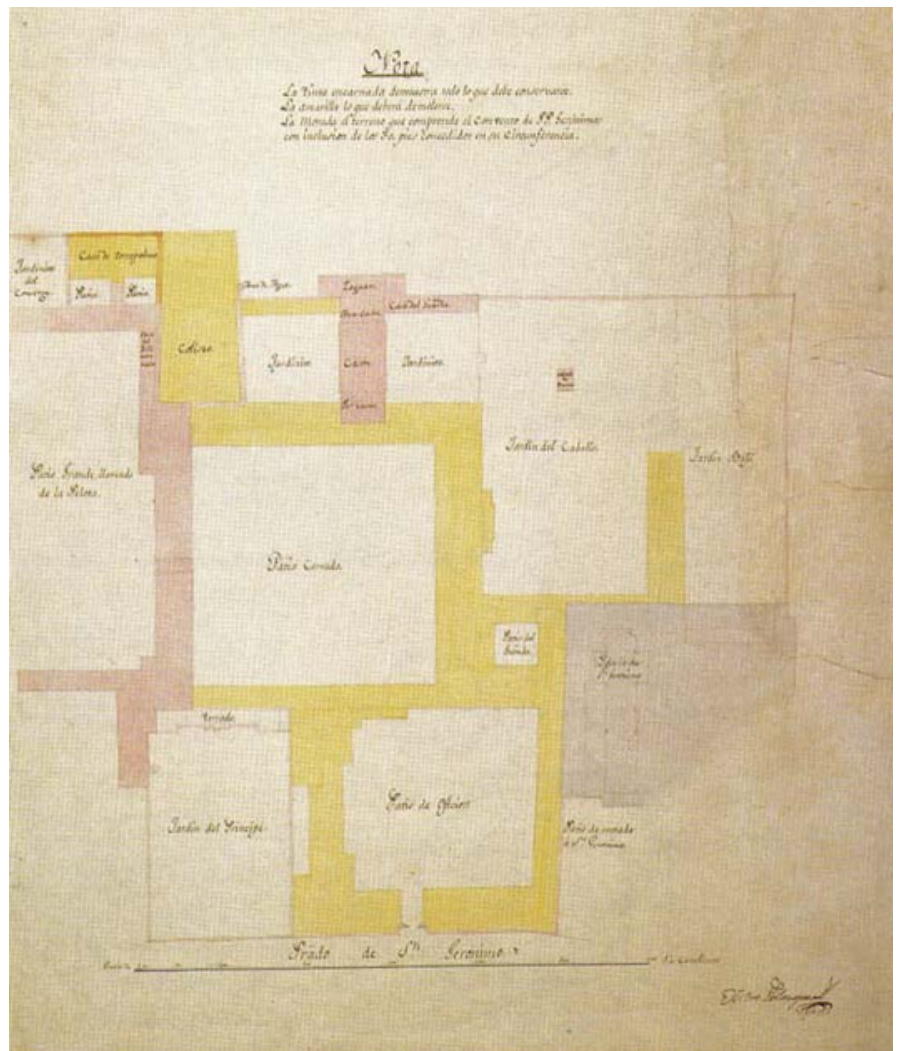

Fig. 6. Plano de las habitaciones del pintor de cámara Aparicio, AGP 856 
Debido a la decisión del general Espartero de trasladar el Museo de Artillería, del viejo edificio del Parque de Monteleón a lo que quedaba del antiguo Palacio del Buen Retiro, esta construcción conoció a lo largo de la segunda mitad del siglo XIX su más profunda y sistemática obra de rehabilitación y reforma, conforme con las nuevas exigencias y, sobre todo, con las funciones museísticas que iba a desarrollar. Planteando para el edificio una nueva tensión dialéctica entre su pasado fundacional, su entorno actual y su novedosa función contemporánea.

El traslado fue rápido, como apresurado, entre el 12 y el 14 de agosto se llevó a cabo la mudanza al Salón de Reinos y a los dos aposentos laterales para que las nuevas instalaciones del museo estuviesen preparadas para la inauguración al público, que fue el 23 de octubre de $1841 . .^{16}$ El edificio quedaba como parte del Patrimonio Real y por su uso se pagaba una renta de más de 17885 reales. Una condición, la del alquiler, que, en un primer momento, contribuyó al degrado del edificio, pese a los esfuerzos manifiestos de los nuevos inquilinos. Las condiciones del edificio debían de ser tan precarias que pocos meses antes de realizarse el traslado del Museo de Artillería se verificó un hecho que las propias fuentes de la época definieron como «ruin»; hablamos del derrumbe de una parte del edificio en sus elementos estructurale algo que no debe de extrañar si cotejamos la descripción con una rara imagen fotográfica de la época o de poco posterior [Fig. 7].$^{18}$ Estas circunstancias no fueron ocasionales y se vinieron repitiendo de forma sistemática a lo largo de las tres décadas siguientes, provocando las quejas de los militares y ocasionando a la vez un notable desembolso económico por su parte. No obstante, la actividad del museo no cesó incrementando las colecciones, su estudio y difusión llegando hasta a publicarse un catálogo y a elaborar algunos estudios de conjunto en los que se empezaba a vincular la reforma con la nueva función del edificio, ${ }^{19}$ aunque

16. A. Carrasco y Sayz, Memoria Histórico descriptiva del Museo de Artillería escrita en 1874, Madrid, 1876 (escrita en 1874), Imprenta de la viuda de Aguado e Hijo, p. 30.

17. El 23 de octubre se abrieron las visitas para el público martes y sábados de 9 a 12 h y de 14 a 16 h. Las características de apertura al público resultan tener una gran importancia a la hora de evaluar el contexto social en el que se planeará en los años setenta del siglo xix la rehabilitación del edificio; cf. A. CARRASCO y SAYZ, Memoria Histórico descriptiva del Museo de Artillería escrita en 1874, op. cit., p. 31; A. DE CARLOS PEÑA, Museo del Ejercito Isabelino, Madrid 1992, Instituto de Estudios Madrileños, p. 8.

18. En estos términos: «En la $2^{\text {a }}$ Crujía de la fachada principal de este edificio se ha hundido un trozo del tranquil que forma el tejado de la parte interior y crujía que da al patio del centro hay una escalera provisional de subida a los desvanes para cuya colocación fue preciso romper una bóveda, que el transcurso del tiempo la ha hecho resentir en algunos trozos que amenazan ruina y encima de dicha escalera se halla una línea rota y próxima a caerse esta parte del tejado...reparación urgente y para ejecutarlos es indispensable reconstruir el tranquil y reponer el tejado hundido: colocar tres tercias nueva y amparar los trozos de la otra bóveda que amenaza ruina y formar de nuevo la línea»; AGM- Segovia, sec. $2^{\text {a }}$ División $8^{\mathrm{a}}$ leg. 456 caja 1, exp. 1, ref. 25 mayo 1841.

19. Los espacios y las funciones se desarrollaron, como lo demuestra la adquisición en 1856 de un laboratorio fotográfico o la instalación de unos talleres de imprenta y la edición en 1849 del primer catálogo del Museo que incluía aproximadamente novecientas entradas; mientras que el primer catálogo se edita a instancia de D. León Gil de Palacios, primer director del Museo y Cuerpo de Artilleros, Catálogo de los 
no se concretaba su naturaleza en términos arquitectónicos. ${ }^{20}$ Finalmente, en este mismo sentido debemos de interpretar las referencias de Pascual Madoz, quien explicaba la necesidad de ampliación de las instalaciones del Museo, algo que no se había podido llevar al cabo por los escasos recursos del Estado. ${ }^{21}$ En otros términos, a la sistematización museística a la que hacíamos referencia anteriormente, no se correspondieron iguales actividades en lo relativo a los elementos estructurales del edificio. En estos se intervino de forma ocasional por medio de soluciones parciales útiles solo a modo de remedios paliativos para episodios y problemas concretos; como en 1862, cuando se solicitó permiso al Patrimonio Real para realizar algunas reformas en el interior y en el exterior. ${ }^{22}$ Las obras planteadas por Herrera se autorizaron bajo el concepto de su provisionalidad y su reversibilidad. Algo parecido ocurrió al año siguiente cuando se hizo otra petición similar, con motivo de otro requerimiento de la misma índole, al que se añadía la petición de arrendar uno de los locales anexos para exponer parte de los fondos expuestos, la contestación del Patrimonio

objetos que contiene el Real Museo Militar a cargo del Cuerpo de Artillería, Madrid, 1856, Imprenta de Tejado, para su repercusión histórica véase A. CARrasco y SAYz, Memoria Histórico descriptiva del Museo de Artillería escrita en 1874, op. cit., p. 33.

20. En estos términos: «este año merece particular recuerdo por un proyecto de reforma del museo, presentado por la junta superior facultativa, de orden del Director General, Marqués de la Habana, bajo las siguientes bases y entendiendo que se podía aplicar un millón de reales a dicha reforma únicamente para la localidad. 1) obtener del Real Patrimonio toda la planta baja, para colocar pieza proyectiles y efectos de grandes pesos 2) Obtener del mismo una zona de terreno al Sur, o sea a espaldas del Edificio para construir un tinglado de Hierro y cristal para colocar los modelos al natural de toda clase de piezas, proyectiles, montaje y carruajes del moderno material 3) Que todos los establecimientos al construir efectos enviaran uno de Muestra al Museo 4) que de adquirieran en el extranjero colecciones de armas instrumentos y efectos militares 5) que se dotara el museo con un maestro mayor hábil y un operario para construir los modelos y efectos militares. 6) que se ilustrara el catálogo con un álbum fotográfico del Material del Museo 7) que se elevara la consignación al doble, es decir a 8.000 reales mensuales»; cf. A. CARrasco y SAYz, Memoria Histórico descriptiva del Museo de Artillería escrita en 1874, op. cit., p. 40-41.

21. Una expresión clave para entender el contexto: «la penuria que desde entonces se ha visto el Erario, no ha permitido se diese a este Museo toda la extensión de que es susceptible» P. MADoz, Diccionario Geográfico-Estadístico-Histórico de España y de sus posesiones de Ultramar, Madrid, 1847, tomo x, p. 847.

22. Dicha petición iba respaldada por un informe redactado por el académico y arquitecto Carlos Herrera, quien daba un panorama desolador de las condiciones del edificio, planteando la necesidad de las intervenciones hasta para asegurar la incolumidad de los visitantes y evitar «desgracias personales que llegarían a ser terribles si ocurriese la catástrofe en las horas por ejemplo en que se permite la entrada al público». En el resto de su informe Herrera entra en el detalle de las intervenciones identificando la necesidad averiguar y reforzar el grado de resistencia del suelo del piso principal para evitar hundimientos, bajo el peso de las piezas expuestas en estos términos: «a pesar de que a primera vista aparece en estado regular de solidez, no se puede conocer exactamente sin hacer una obra costosa y embarazosa... poner a los interiores de los muros de la fachada y a los la traviesa unas carreras descubiertas, sostenidas por pies derechos, para cortar el vano de la crujía y conseguir que las paredes de los maderos que sostienen este piso estén en buen estado por lo cual aumentará su resistencia, tan necesaria en todos los sitios, u en especial en los que ocupa la sala tercera, en donde hay un exceso de peso que de todos modos debe disminuirse». Además, el arquitecto aconsejaba el desalojo de los inquilinos que ocupaban diferentes aposentos del palacio, y particularmente hacía mención al grave daño que procuraba la presencia de unas buhardillas, de las que aconsejaba la eliminación, al techo del Salón de Reinos y a las pinturas al fresco que allí se encontraban «la supresión y demolición del gran número de boardillas habitables que existen en el centro de la crujía que constituye el vano de la cubierta... por el deterioro que se produce en maderas del suelo y tirantes de dichas armaduras o cubiertas, por el continuo tránsito, golpes, y humedades, encima del magnífico techo del salón llamado de los Reynos».; cf. AGM- Segovia, sec. 2a División 8ª leg. 456 caja 1, ref. 21 enero 1862. 


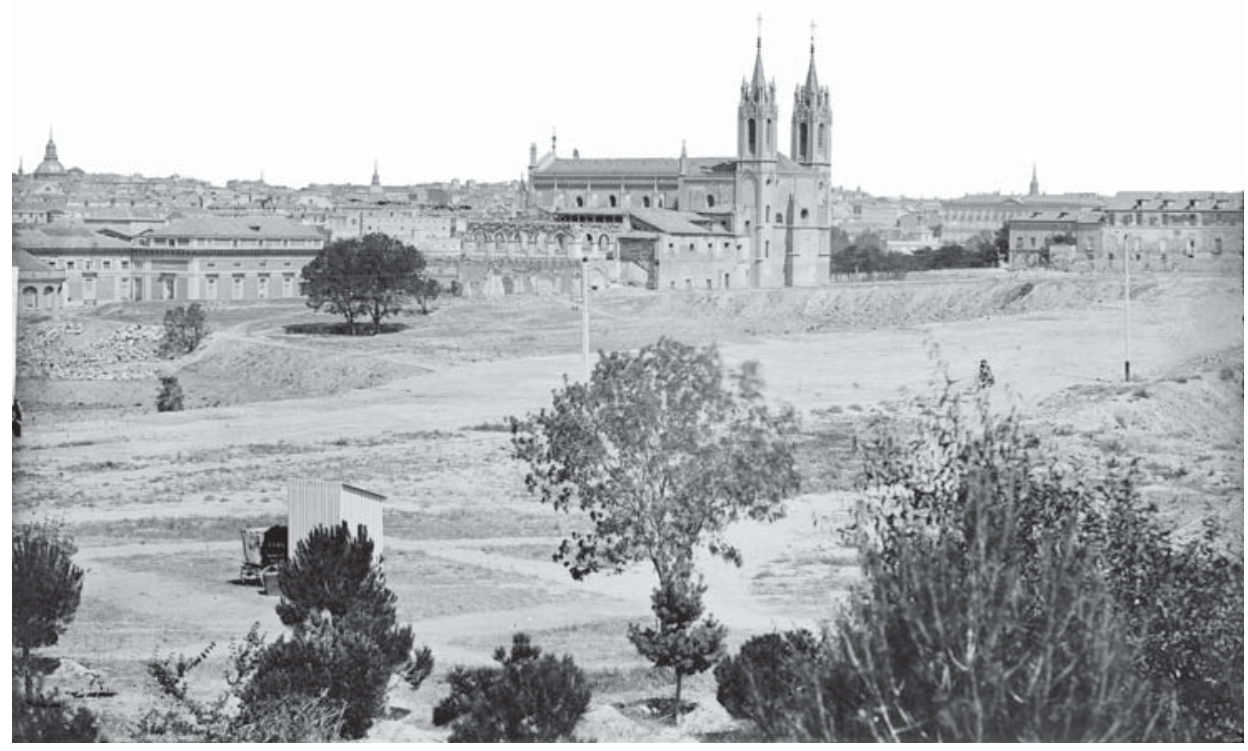

Fig. 7. Fotografía de la zona de los Jerónimos, incluye la fachada posterior del edificio del Buen Retiro con sus correspondientes anexos en el lado Oeste, posterior a 1856, Archivo Vernacci, 2885, IPHE

Real hizo vislumbrar la posibilidad de una demolición total del edificio para el aprovechamiento del solar, en el marco del ambicioso plan de desarrollo y reforma urbanística de la zona proyectado bajo Isabel II. ${ }^{23}$ La situación llegó a su extremo hacia la primavera de 1865 , cuando se incluyó, en el proyecto de ley correspondiente al embellecimiento urbano de la Villa de Madrid, la posibilidad de derribar por completo el edificio. ${ }^{24}$ La citada proposición de ley no prosperó y, de todos modos, llevó a los administradores del Museo a gestionar un hipotético traslado, ${ }^{25}$ a la vez que, por otro lado, intentaban que se le concediese el edificio en su totalidad. ${ }^{26}$ Acontecimiento que se produjo en 1871, cuando se ordenó al Ministerio de Hacienda la entrega del estable libre de cargas, personas y enseres ajenos al Museo. ${ }^{27}$

23. Herrero Fernández-Quesada, M.․․ D., Orígenes del Museo del Ejercito, Madrid 1999, p. 109-110.

24. Agm- Segovia, sec. $2^{\mathrm{a}}$ División $8^{\mathrm{a}}$ leg. 456 caja 1, ref. 13 Mayo 1865.

25. AgM- Segovia, sec. $2^{\mathrm{a}}$ División $8^{\mathrm{a}}$ leg. 456 caja 1, ref. 14 julio 1865; en este mismo marco hay que interpretar el plano de situación del Buen Retiro que se encuentra en el mismo archivo de Segovia, y que acompaña el expediente.

26. AgM- Segovia, sec. $2^{a}$ División $8^{a}$ leg. 456 caja 1, ref. 20 octubre 1869.

27. Agm- Segovia, sec. $2^{\text {a }}$ División $8^{\text {a }}$ leg. 456 caja 1, ref. 4 septiembre 1871 
A partir de esta fecha los artilleros dispusieron por fin del edificio y empezaron a plantearse su remodelación de forma sistemática con el fin de que su Museo pudiera estar a la altura de las colecciones que albergaba y de la masa de visitantes que tenía. En 1873 la Junta Superior Facultativa, consideraba expresamente la conveniencia de que el Museo permaneciera en el Buen Retiro, por cuanto «sería muy difícil encontrar ni mejor local ni mejor situación». Un planteamiento que hacía necesario, por otro lado, un proceso de ampliación en los solares aledaños de forma coherente con las intenciones urbanísticas de la época. ${ }^{28}$ En el mismo informe se subrayaba también la necesidad, para la buena conservación del edificio, de que se procediera a «una restauración para que no desarmonice la hermosura del barrio que en aquellos solares se va a levantar». Por esta razón se decidió que la restauración siguiera las pautas estilísticas del edificio con anterioridad a la invasión francesa y se planteó que a este conjunto se le añadiría una plazuela [Fig. 8].$^{29}$ Dejando clara de esta manera la apuesta por una reconstrucción según modelos historicistas fundados en la memoria arquitectónica propia de los modelos de la dinastía habsbúrgica en España y que, además, entonaran con el nuevo entorno urbano; corrigiendo de facto la percepción de la historia real por medio de patrones ideológicos propios de finales del siglo xIx. Sin embargo, de otro apartado del mismo informe, se desprenden algunos de los problemas estructurales y museísticos a los que había que poner remedio, ${ }^{30}$ justamente debido a la naturaleza originaria de aquel edificio. En lo que se refiere al aspecto exterior, dicha propuesta planteaba añadir en la parte posterior dos alas perpendiculares en los extremos del edificio y enlazarlos por medio de un cobertizo haciendo desaparecer las construcciones irregulares adosadas al cuerpo principal y de esta manera restituir homogeneidad al conjunto, como se quiere demostrar por medio de un croquis adjunto a la relación [Fig. 9], ${ }^{31}$ reedificando, además,

28. «[...] obtener la cesión por el Ayuntamiento de esta villa de un espacio delante y detrás del edificio, con objeto de rodearlo con una verja, y en la explanada que comprenda, colocar al natural la artillería de diferentes épocas con sus correspondientes montajes [...]»; AGM- Segovia, sec. 2a División $8^{\text {a }}$ leg. 456 caja 1 , ref. 31 diciembre 1873 .

29. «[...] una espaciosa plazuela alrededor cerrada con verja dentro de la cual se expongan la artillería del siglo actual rayada y lisa y las colecciones que puedan reunir de los siglos anteriores con sus montajes y juegos de armas resguardados en ligeros y elegantes casetones, con plantaciones de jardín intercaladas [...]»;

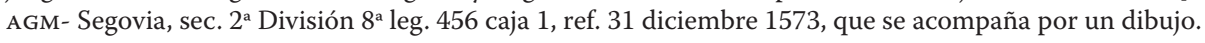

30. Haciendo especial hincapié en las cuestiones relativas a hechos concretos como que las humedades de la planta baja que seguían representando un problema, que el acceso a los despachos era problemático en cuanto había que cruzar las grandes salas de exposición, que los talleres resultaban, pequeños, que no había alojamiento para los empleados y que se carecía de agua corriente. En otros términos el local en su conjunto empezaba a resultar pequeño y poco adecuado para las colecciones, además, se notaba una falta de luz especialmente en las salas de las armas, y se necesitaba una segunda escalera de comunicación ente la planta principal y la baja con el fin de agilizar el desplazamiento de los visitantes: «que debería de estar situada el extremo opuesto de la escalera existente para conseguir que las visitas recorran ambos pisos seguidamente sin retroceder ni cruzarse los que entran con los que salen..»; AGM- Segovia, sec. 2a División $8^{\text {a }}$ leg. 456 caja 1, ref. 31 diciembre 1573.

31. AgM- Segovia, sec. $2^{\text {a }}$ División $8^{\text {a }}$ leg. 456 caja 1, ref. 31 diciembre 1573, que se acompaña por un croquis. 


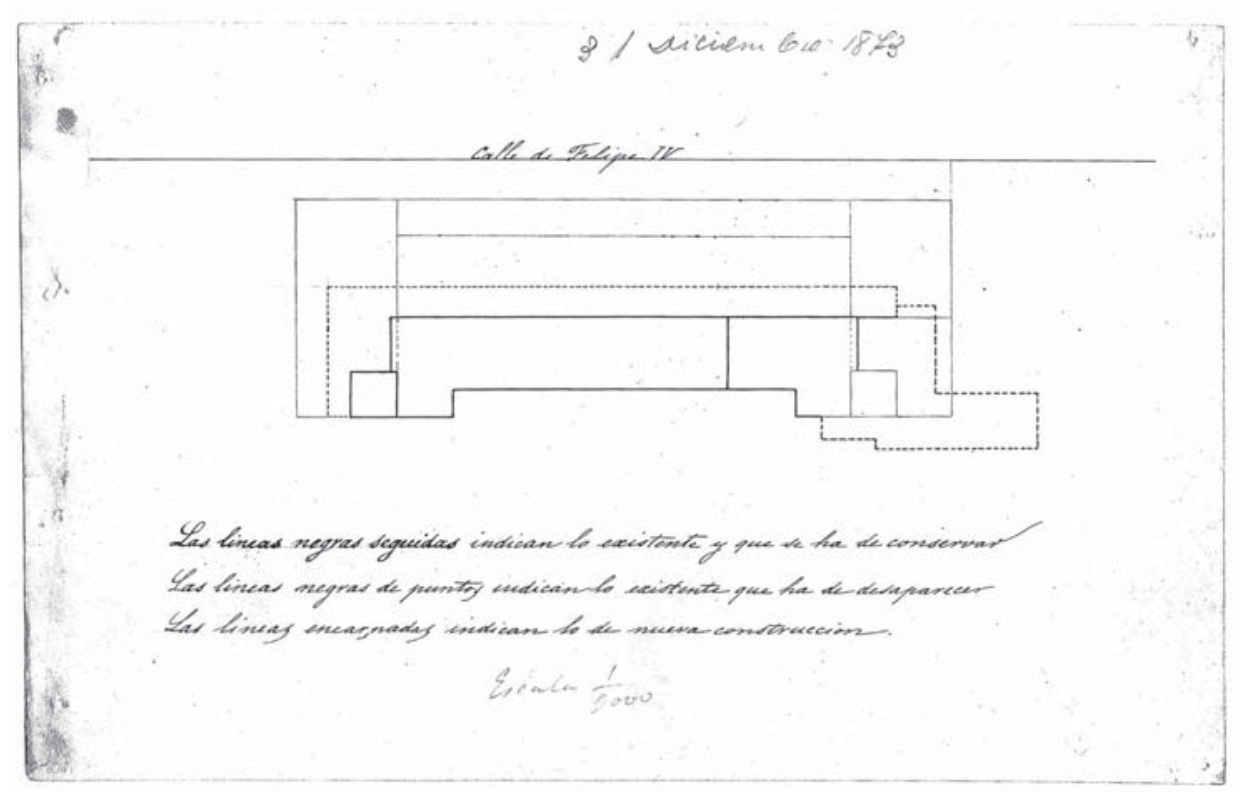

Fig. 8. Croquis de los terrenos que circundan el Museo de Artillería con idea del plan de reforma del edificio, 1876

la torre de la izquierda, ${ }^{32}$ cuya definición nos devuelve a la concepción de la crujía como «fachada» de palacio de la que ya hablamos anteriormente.

Las obras planteadas habían producido un empeño proyectual significativo que llevó a los responsables del Museo a pedir una valoración a la Comandancia de Ingenieros de Madrid, frente también a la demolición de algunos de los edificio anexos para la definición de los solares colindantes. El historicismo tenía que pagar sus cuentas a la historia o por lo menos disimular sus semblantes. El coronel responsable de la Comandancia de Ingenieros redactó una memoria que remitió en octubre de 1874 al capitán general. En ella registraba las condiciones del edificio y manifestaba sus preocupaciones en lo referente a la fábrica de mampostería, ${ }^{33}$ no solo por su antigüedad, sino más bien por su mala calidad; ${ }^{34}$ llegando hasta plantear la demolición de

32. Se plantea «restablecer la torre de la izquierda del edificio en el medio de un cuerpo saliente haciendo simetría con otro igual en la torre que existe a la derecha y regularizando los huecos de las luces por ambas fachadas»; AGM- Segovia, sec. 2a División 8a leg. 456 caja 1, ref. 31 diciembre 1573.

33. «he reconocido el edificio que ocupa el Museo de Artillería y resulta que por la nueva alineación y rasante de las calles nuevas, han derribado parte del edificio de pabellones que había adosado al torreón de la fachada principal»; AGM- Segovia, sec. 2a División $8^{a}$ leg. 456 caja 1, ref. 14 octubre 1574.

34. «por estar hecha de trozos de diferentes épocas y de mala construcción, y gracias, a lo buena que son en su mayoría las maderas de los entramados se sostiene esta parte del edificio» AGM- Segovia, sec. $2^{\text {a }}$ División $8^{\mathrm{a}}$ leg. 456 caja 1, ref. 14 octubre 1574. 


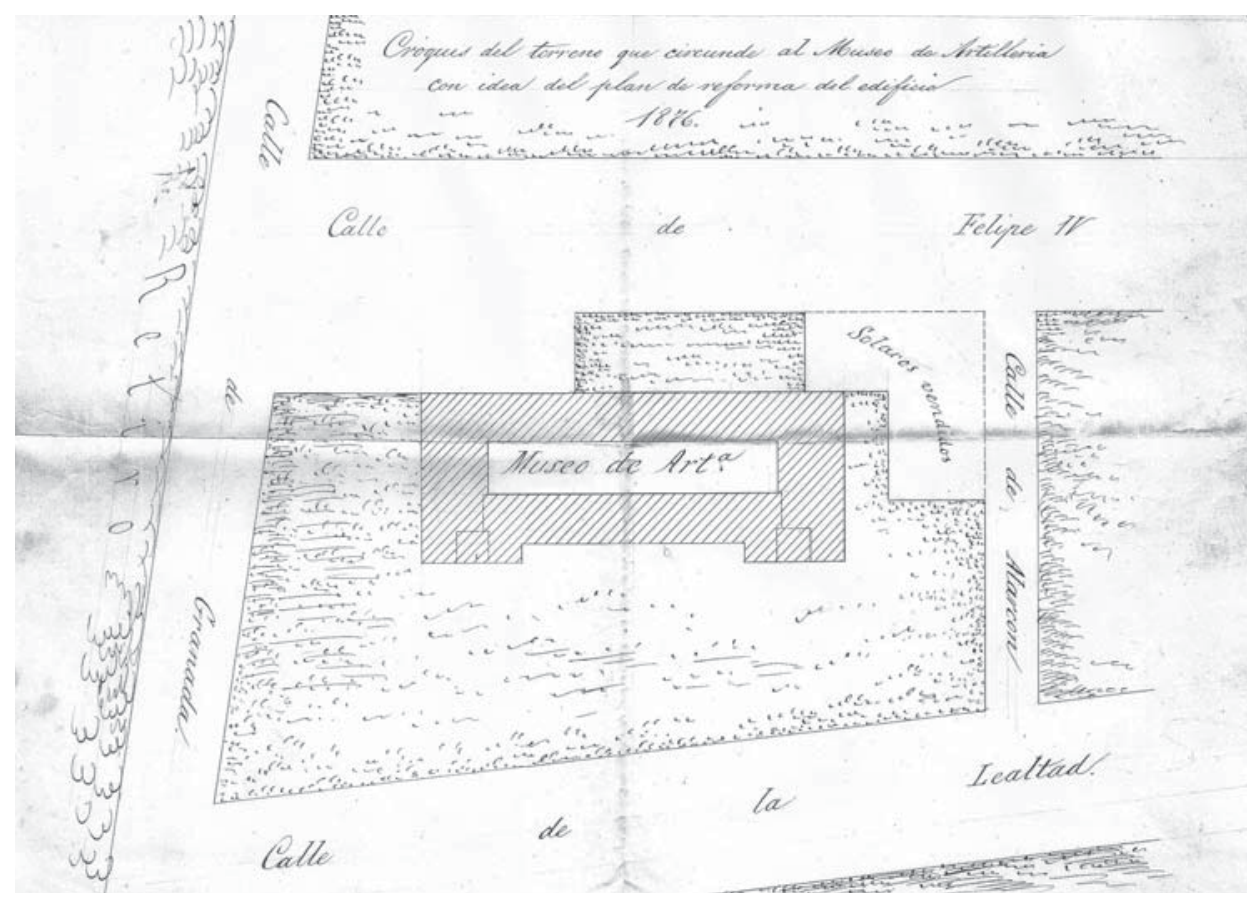

Fig. 9. Anexo al plan de reforma de 1873 indicando las zonas de intervención en el edificio, AGM- Segovia, sec. 2a División 8 ${ }^{\text {a leg. }} 456$ caja 1, ref. 31 diciembre 1873

partes del edificio. Al año siguiente la Junta Superior Facultativa emitió un informe sobre estas cuestiones en el que hacía propio el proyecto de reforma de 1873 y recordaba las necesidades de adecuar el edificio con el barrio que le circundaba, por lo que volvía a reiterar sus peticiones al Ayuntamiento llegando a plantear que se incorporara al conjunto del museo y de sus jardines la llamada «Puerta del Ángel o de la Fama» que quedaba como una ruina aislada en aquel momento. ${ }^{35}$

A estos mismos años debemos la redacción y posterior edición del texto de Adolfo Carrasco en el que, por un lado, se resumen las hazañas del Museo de Artillería y, por otro, se plantea su desarrollo bajo una estricta perspectiva museográfica. Una circunstancia que trasciende las cuestiones exclusivamente vinculadas al Museo del Ejército, y convierte la Memoria de Carrasco y Sayz quizás en uno de los primeros, sino el primer plan museográfico redactado y publicado en España. A lo que hay que añadir el hecho de que el contenido de este texto se vino elaborando desde 1873, siendo redactado en 1874 y llegando a ser licenciado para la imprenta en agosto de 1875 y

35. AgM- Segovia, sec. 2a División $8^{\text {a }}$ leg. 456 caja 1, ref. 27 noviembre 1875. 
por su requerimiento por parte de instancias superiores y con la clara finalidad de soportar las labores de elaboración de un proyecto de reforma sustancial del edificio del Buen Retiro [Fig. 10] ${ }^{36}$ De hecho la Memoria empieza haciendo un recorrido histórico por las principales etapas del Museo de Artillería en su emplazamiento en el Buen Retiro, a la vez que resumía las líneas esenciales de la historia de aquel mismo edificio desde su construcción. ${ }^{37}$ La parte más interesante la encontramos cuando Carrasco plantea, en el apartado llamado Cuestión del edificio, la reconstrucción de los acontecimientos más recientes y las propuestas para el futuro donde se alaba la reforma del edificio para su mejoría y la del barrio entero. ${ }^{38}$

Acto seguido Carrasco y Sayz pasa a ofrecer una pormenorizada descripción del estado del edificio, de la distribución de las salas y de las piezas que se

36. A. Carrasco y Sayz, Memoria Histórico descriptiva del Museo de Artillería escrita en 1874, Madrid, 1876 (escrita en 1874), Imprenta de la viuda de Aguado É Hijo.

37. A. Carrasco y Sayz, Memoria Histórico descriptiva del Museo de Artillería escrita en 1874, op. cit., pp. 29-47.

38. «Una cuestión que ha preocupado en estos últimos años a los encargados del Museo, que ha sido la del edifico. Sabido es ya que la parte ocupada por aquel era el piso principal y parte de la planta baja, hallándose el resto de este las buhardillas, que caen sobre los salones, habitados por varios particulares enteramente extraños al establecimiento; y que la expresada localidad costaba al Estado 17885 reales anuales pagados al Real Patrimonio por semestres vencidos. Por ley del 12 de mayo de 1865, fueron cedidas varias fincas del Real Patrimonio a la Nación y en 1868 tomó de toda posesión la Hacienda Nacional. En vista de esto, el director del Museo expuso al de Artillería, en 6 de junio de 1869, la anomalía de seguir pagando aquel alquiler el ministerio de la Guerra al de Hacienda, y los inconvenientes de tener en el edificio habitantes particulares, en su mayor parte gentes pobres y sin responsabilidad, y por lo tanto convenía solicitar la cesión completa en favor del cuerpo, que como directamente interesado en el brillo del establecimiento, era quien mejor podría mirar para la conservación del Edificio, posible mediante oportunos reparos, a pesar del estado de deterioro a que había venido a parar por el descuido en que lo había tenido el Patrimonio y que amenazaba a ser mayor en lo sucesivo. En 1869 el Regente accede a la petición pero con una serie de disposiciones económicas. En 13 de mayo de 1870 se hizo ver lo anómalo de semejante disposición añadiendo que en todo caso la entrega no se había verificado, puesto que el recaudador del Patrimonio todavía estaba cobrando en 1869 los alquileres a los inquilinos, ya que estos seguían habitándoos sus cuartos y se reclamaba su expulsión y mandato para la toma de posesión de todo el edificio por el cuerpo, así como la agregación de una porción de terreno por delante y detrás de aquel, sin canon ninguno en favor del estado, por ser una parte de este del ministerio de la Guerra y cuerpo de artillería. Habiéndose empezado el 20 de marzo de 1871 el derribo de las casas que formaban la entrada del retiro, se produjeron las reclamaciones y el resultado final fue la orden del ministerio de la guerra del 18 de agosto de 1873, determinando que el edificio pertenecía y debía de ser entregado al cuerpo en su parte desocupada y sucesivamente los demás medida que fueran vacando las habitaciones, mediante entrega formal por parte de la comisión de derechos y propiedades del estado. La entrega se empezó por un local de la planta baja, lo que tuvo efecto en septiembre inmediato, y de cuya operación se levantó acta formal en el mismo día. Posteriormente no hubo entrega ninguna hasta 1874, que se hizo de dos boardillas, ni se pudo conseguir la expulsión de los vecinos restantes a pesar de repetidas reclamaciones, haciendo presente los prejuicios que causaba aquella servidumbre, tanto en cuanto a la seguridad como a la conservación y falta de local del Museo,- Queda definitivamente por el cuerpo el edificio- Al cabo en Marzo de 1874 mandó terminantemente el presidente del consejo de ministros que los vecinos desalojasen sus viviendas y se hiciesen cargo de ellas el Museo en un breve plazo que quedó cumplido en 14 de abril siguiente. Plan de restauración del Edificio. Entre tanto se formuló un plan de restauración y ensanche del edificio, para darle la necesaria seguridad, solidez amplitud y belleza que merece por su destino y por el paraje que ocupa en medio del Barrio o paseo que se proyectaba. Este asunto se halla en tramitación y no hay duda que su realización sería muy ventajosa para el establecimiento» A. Carrasco y SAyz, Memoria Histórico descriptiva del Museo de Artillería escrita en 1874, op. cit., pp. 48-51. 


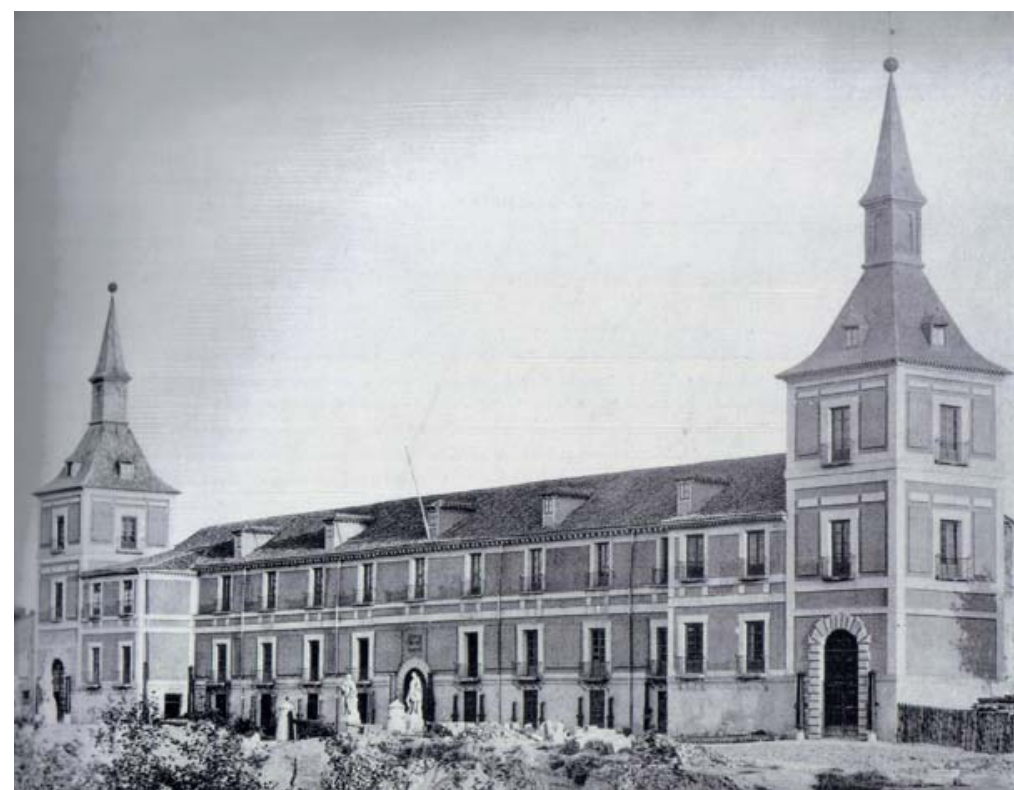

Fig. 10. Fotografía del estado del edificio tras el proceso de reforma planteado en 1874

\section{encontraban en ellas, según una rigurosa mirada museística haciendo especial referencia a la funcionalidad e historia de cada aposento. ${ }^{39}$}

39. «El edificio que ocupa el Museo de artillería es lo único que resta del Palacio del Buen retiro, como en otra parte he dicho. se extiende en dirección E.O. por la subida del Prado al Retiro, entre el Museo de Pinturas y el Obelisco del dos de Mayo. Su forma es rectangular, con 81 metros de longitud en la expresada dirección 12.30 d latitud de N. a S. y 12 de altura su fachada principal, que la de norte; presentando esta en sus extremos dos cuerpos salientes con 4.50 metros de avance 26.80 de largo, de los cuales el del lado oriental sustenta una de las torres que flanqueaban el antiguo palacio, y contiene el portal y escalera principal. En el extremo opuesto hay unidas al edificio otras construcciones más modernas irregulares y poco seguras, que le afean, y por detrás o se a la parte Sur una tapia formando un patio tan largo como la fachada y de unos 6 metros de anchura. Esta el edificio completamente aislado, y con una elevación media de 2,60 metros relativamente a la vía explanada entre el monumento del Dos de Mayo y la entrada al parque del retiro con el proyectado nombre de calle de la Libertad. Los objetos que constituyen el museo se encuentran distribuidos entre la planta principal y la baja del edificio, los más ligeros manuables y delicados -en aquella, y los más pesados como piezas, carruaje municiones de artillería en la última. La primera se compone de tres bellos y espaciosos salones corridos, y de varias habitaciones pequeñas pertenecientes a las construcciones accesorias, que ha sido preciso agregar por no caber en aquellos objetos sucesivamente adquiridos. La planta baja a la que se desciende por una estrecha y mezquina escalerilla ocupa el espacio comprendido debajo de dicho primer salón y cerca de la mitad del siguiente o segundo, y está interceptada por varias paredes que quitan la claridad y desahogo que este local necesita, y podría tener a pesar de la escasa altura de su techo. Ambas plantas reciben sus luces por las dos fachadas (excepto en las partes que cubren los cuerpos salientes indicados), la baja de una de sus puertas pequeñas, y la principal mediante balcones al nivel de su piso y ventanas encima, correspondiéndose entre sí con las puertas de abajo en las dos fachadas; de modo que estas, con sus tres filas de huecos, aparentan otros tantos pisos, sin contar con las boardillas. El resto de la planta baja consta de varios departamentos que solo pueden servir en su actual estado para almacenes o depósitos de cosas viejas. Planta principal - Primer salón. El primer salón de la plana principal se supone ser el antiguamente llamado antecámara de la Reina, mide 18,40 metros de longitud EO, 9.97 metros de anchura, igual que a la de los dos siguientes, así como la altura que es de 
Se trata de un documento único capaz de devolvernos con extrema precisión todos y cada uno de los elementos esenciales del estado del edificio con anterioridad a la reforma planteada en 1880. Hacemos mención en tal sentido de las referencias a los colores de las paredes, a las características de los suelos, al hecho de que se explique con detenimiento el uso que se había dado a los huecos de entre las paredes que separaban el Salón de Reinos de los dos salones secundarios y finalmente se atribuyen al pintor Aparicio algunas de las obras realizadas en las habitaciones del lado oeste del edificio [Fig. 11]. Un

8.37. Tiende dos balcones al sur y otro al norte, y la puerta principal; sobre estos tres balcones otras tantas ventanas y tres más en los intermedios de las anteriores. En medio del testero del E hay una puerta que comunica con el despacho del Capitán, y en el opuesto la que da paso al segundo salón y otra cerca del ángulo del norte correspondiente a la escalerilla de la planta baja. El techo es de bóveda y está blanqueado: las paredes pintadas de azul, y el pavimento de baldosa ordinaria, como todos los demás. Es de advertir que este salón fue más largo en sus principios, y le quitaron 3 metros en su inmediación al segundo por medio de una pared formando un hueco entre los dos salones, lo que se conoce a simple inspección de la bóveda. Este hueco, dividido en dos pisos, contiene en el superior la oficina de la Administración militar, con tres ventanas al primer salón e igual número al segundo, además de las dos abiertas al exterior en las fachadas N y S; y en edificio inferior, a parte del paso de uno a otro salón, hay al lado del sur el despacho del Subdirector con un balcón, y al del Norte las escalerillas de subida a la dicha oficina y de descenso a la planta baja, con otro balcón. Aunque parezca esta reseña enfadosa y prolija, conviene hacerse cargo bien de todo para comprender la necesidad de las reformas y mejoras que más adelante se proponen. Segundo Salón llamado de Reinos. El segundo salón es un magnifico rectángulo de 34.54 metros de longitud, con la misma anchura y elevación que el anterior. Recibe las luces por diez balcones, repartidos simétricamente por mitad en los dos costados y coronados por otras tantas ventanas. El lienzo frontero a la puerta de entrada hay otra igual que guía al tercer salón. El de que ahora se trata es titulado Salón de Reinos, por haberse congregado en él las Cortes desde los últimos reinados de la Casa de Austria hasta 1789 según lo queda dicho en la nota 14, en la que se pueden ver también los pormenores de la decoración de la bóveda. Tercer salón o sala de Armas, antes sala de Pintor. El tercer y último salón es de iguales dimensiones que el primero, con tres balcones y seis ventanas sobre ellos al Sur (tapiados los primeros y mitad de las segundas); un balcón también tapiado al Norte, y encima una ventana muy grande, reemplazando aunque en un lugar más bajo e intermedio a la natural del edificio, que estaba próxima al salón de Reinos, haciendo juego en la fachada con las correspondientes al primer salón. Hay otra puerta cegada en el testero final, correspondiente a la que en el primero comunica con el cuarto del Capitán. En esta sala, que actualmente es la de armas, era antes conocida por la del Pintor, a causa de haber tenido en ella su estudio D. José Aparicio, que es quién abrió el expresado ventanón. También este salón tiene interceptado un espacio de más de tres metros por la parte contigua al segundo, cerrando entre ambos un hueco aprovechado en medio para pasaje, y a los dos lados para dos piezas con sus balcones, la una destinada a gabinete de experimentos, y la otra a cuarto de Conserje; teniendo este una escalerilla para subir al sobrado que cubre a los anteriores y tiene dos ventanas opuestas encima de los balcones por dos puertecillas que dan al tercer salón cerca de los ángulos. Piezas agregadas- En los opuestos ángulos hay otras puertecillas, la del sur para el despacho del Director, y la otra para cinco piezas de las construcciones accesorias, que en otro tiempo fueron habitaciones, y hoy, a pesar de sus malas condiciones, sirven para exponer objetos del Museo y para oficina de grabado y dibujo. Planta baja- La planta baja, en la parte destinada a Museo, se compone de cuatro salas, dos al norte y dos al sur, formadas por dos paredes que se cortan en cruz en una en el eje del piso y otra trasversal; existiendo además el hueco de la escalera entre las dos salas del norte. Reciben luz estas cinco piezas por cinco puertas ventanas al sur y cuatro al norte. El resto de la planta baja lo constituyen varios departamentos, solo útiles para almacenes y depósitos, como queda apuntado. En la planta baja de las construcciones adyacentes tiene sus habitaciones el Conserje y el guarda o vigilante nocturno, quedando otra parte inhabitable. El hueco debajo de la escalera sirve de cuerpo de guardia. Boardillas y sótanos. Debajo de los expresados departamentos de la planta baja, que sirven como almacenes, hay unos sótanos sin aplicación. Encima de los salones existen las boardillas, teniéndolas también las repetidas construcciones accesorias. Talleres. En la extremidad de este edificio, y comunicando con él por el portal, se ha construido un cobertizo, que es en donde están los talleres, los cuales comunican también por medio de una escalerilla con la planta principal, en el pasillo que une el cuarto del Capitán con el primer salón» A. CARrasco y SAYz, Memoria Histórico descriptiva del Museo de Artillería escrita en 1874, op. cit., pp. 51-54. 


\section{conjunto de informaciones que vienen complementados por el apartado de los Defectos, donde se enumeran las problemáticas arquitectónicas, funcionales y museísticas del edificio con sus correspondientes pormenores. ${ }^{40}$}

40. «Defectos generales del local. Hecha la descripción, pasemos a enumerar los defectos más aparentes del edificio, considerado bajo el punto de vista de Museo. Es preciso admitir, ante todo, que las construcciones adyacentes, tantas veces mencionadas, deben desaparecer, así por su mal estado, como por contrarias al ornato en el punto en que se contemplan, aparte de la mezquindad y mala disposición de sus piezas, enteramente impropias de la importancia y hasta del decoro de un establecimiento como el Museo. Sin la supresión de esta parte, es bien notoria la estrechez y falta de local, que imposibilitan el menor arreglo y clasificación, e impiden exponer a la vista todos los objetos que se poseen, y con más razón los que se vayan adquiriendo; con que una vez eliminada, serán de mucho más sensibles estos inconvenientes, y es menester a todo trance evitarlos. Defectos de la planta principal- Con esto mismo se complica la forzada distribución actual de las dependencias. Ya se ha visto que la Pagaduría, despacho de los Gefes y Capitán, gabinete de experimentos, ofician de grabado, y dibujo y cuarto del Conserje, están situados en los salones del Museo o contiguos a ellos, con su entrada indispensablemente por los mismos; y hasta para tener con seguridad la caja de caudales, se ha aprovechado en la planta baja un hueco de la pared, medianero con el cuerpo de guardia. Resulta de esta distribución, que no solamente es imposible cerrar las puertas de los salones que contienen los modelos y demás efectos cuando no hay exposición o limpieza sino que hasta los balcones tienen que estar abiertos el día entero, con grandes riesgos para la seguridad y daños para la conservación de las cosas, en razón del tránsito inevitable de cuantos concurren a aquellas dependencias, del polvo consiguiente, sol y calor, tan nocivos para la mayor parte de los modelos y mobiliario. Al propio tiempo, el primero y tercer salón se halla privados de 30 metros cuadrados de extensión cada uno, a causa de las porciones de ellos cercenadas que actualmente se aprovechan para despacho del Subdirector, gabinete de experimentos, cuarto del Conserje y escalerilla de la planta baja, conforme ya se ha dicho. Defectos de la planta baja. En cuanto a esta planta, resulta con 12 metros cuadrados de menos, ocupados por el hueco de la escalera, y además sobrecargado su techo con dos tabicones construidos para aquel cercenamiento que suponen 24 metros cúbicos de fábrica nada menos cada uno. Añádase que los objetos que por su peso y circunstancias están llamados a la planta baja son tan numerosos, que unos se hallan a la intemperie fuera del edificio, otros arrinconados en los almacenes, y los que ocupan el local, hacinados confusamente, sin el desahogo debido para su ordenamiento, clasificación y estudio, presentando el aspecto de un almacén más bien que de un Museo; lo cual es sensibilísimo, en la atención a las preciosidades artilleras que en esta parte se encierran, y muy desfavorable para el concepto de las personas encargadas del establecimiento. A tan lamentable estado de cosas, hay que agregar las malas condiciones de la humedad y ventilación a la que está sujeta la misma planta baja. Estando el piso exterior del edificio más elevado que el interior, y vertiendo el tejado sus aguas en goteras cerca de la pared, sube en esta la humedad a bastante altura, además de extenderse por todo el pavimento, y fácil es persuadirse de lo que sufrirán la artillería, proyectiles y demás objetos de hierro. Contribuye a esto efectos el insuficiente sistema de ventilación, pues las comunicación con la atmósfera son por el Norte las puertas de las habitaciones de que antiguamente se componía este local y al Sur unas ventanas que bajan más que el suelo exterior, no pudiendo abrirse aquellas por su difícil custodia en el sitio público donde dan, y siendo estas ineficaces por su situación en el corral estrecho que, según se dijo, hay en la parte posterior del edificio. Y por si esto fuera poco los muros que forman las cuatro salas y caja de la escalera, interceptan la circulación del aire y de la luz, prestando la apariencia de un sótano poco decente y estorbando para la colocación y distribución de las cosas. Falta de comunicación conveniente entre ambas plantas- Otro defecto de muchísima consideración es el de no existir más entrada ni salida que la escalera principal, sin otra comunicación entre ambas plantas que la escalerilla descrita. Por este motivo los visitantes después de recorrer los tres salones y piezas siguientes, tienen que retroceder por el mismo camino hasta el primer salón para descender a la planta baja, y después subir la misma escalerilla y atravesar el primer salón para salir del establecimiento, encontrándose y tropezando los que van con los que vuelven, con la consiguiente confusión y pérdida de Tiempo; lo cual urge corregir a toda costa evitando el encuentro y haciendo que las visitas no retrocedan y ganen la salida avanzando siempre a lo largo de los departamentos. Ventanas tapiadas- otra falta que o deja de dañar al golpe de vista general y al buen efecto de los objetos en particular, es la irregularidad en la distribución de ventanas y balcones en el primero y tercer salón. Hay varios huecos de ambas clases tapiados, y las ventanas que existen abiertas no lo están totalmente; de lo que resulta mal repartida la luz y bastante oscuro el tercer salón, en que es difícil percibir los detalles de las armas que contiene. Malas condiciones de los talleres. Los talleres no ofrecen las condiciones de tales según las exigencias de la actualidad, en que ya no se trata solo de construcción. El de la fragua (cuarto) es oscuro, y tan reducido que apenas pueden removerse los que están en un espacio tomado 


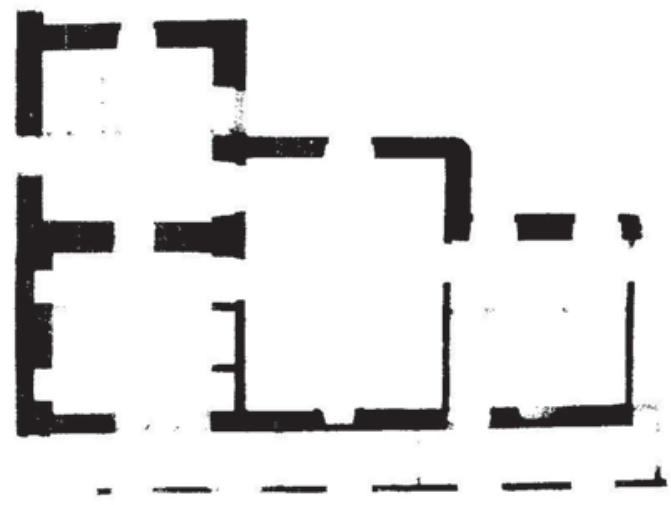

Fig. 11. Observaciones sobre el proyecto de Reforma del Museo d Artillería, AGM- Segovia,

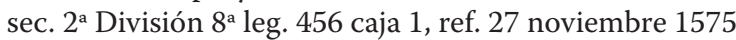

Carrasco incluye en este apartado todo defecto que considera como un estorbo para la función del edificio y que por este mismo motivo pueda ser causa de daño hacia las colecciones o de incomodidad hacia los visitantes. En este sentido parece magistral, en un marco museológico, el conjunto de motivaciones para defender la necesidad de realizar una segunda escalera o la función de una correcta iluminación a la hora de apreciar las colecciones, algo que quedaba desfavorecido por estar tapiadas muchas ventanas. Un planteamiento enfocado a la función museística que queda aún en mayor evidencia, cuando Carrasco propone las intervenciones necesarias para que el Museo de Artillería se convierta en un edificio ejemplar perfectamente integrado en el nuevo barrio y capaz de estar a la altura del Museo de Pintura y del Jardín Botánico, ${ }^{41}$ prefigurando casi el actual Paseo del arte.

a la planta debajo del primer salón. Por ultimo parece conveniente que los talleres aunque cerca y con buena comunicación, estuvieran algo separados del cuerpo principal del edificio, y se aumentasen lo necesario para dibujo, grabado, litografía y fotografía. Falta de agua, Otra contra de suma consideración es la falta de agua para el establecimiento, así para los usos ordinarios de los talleres, limpieza y demás como para los extraordinarios de un incendio. Para rayos- Complemento de la dotación de agua sería un servicio de Para rayos, al que se presta perfectamente la construcción del edificio y que tan indispensable es en un centro que encierra tantas preciosidades irremplazables. Habitaciones para lo dependientes- Tampoco se puede prescindir de habitaciones para ciertos dependientes, como son el conserje, peón de confianza y portero» A. Carrasco y Sayz, Memoria Histórico descriptiva del Museo de Artillería escrita en 1874, op. cit., pp. 54-57.

41.«Resumen de las reformas. En resumen las reformas reclamadas por los defectos que se acaban de enumerar son del tenor siguiente. A los salones de Museo darles todo el ensanche y regularidad posible, procurarle luz y ventilación, decorarlos dignamente facilitar su comunicación, aislarlos de las demás dependencias y aumentar su número; las oficina, los talleres y almacenes, establecerlos con amplitud, comodidad e independencia que sus usos reclaman; $y$ al edificio en general proporcionarle belleza, seguridad y todos aquellos recursos y conveniencias que a un establecimiento público de la clase e importancia del Museo corresponden. Reformas del Edificio- Para alcanzar estos extremos, lo primero es demoler las construcciones adjuntas, tan irregulares, deterioradas y de mal aspecto; restablecer en el ala izquierda la torre que en otros tiempos había para hacer juego con la que aún existe en la derecha, dejándola como está en medio de un cuerpo adelantado, con su puerta; y regularizar la fachada en sus huecos accesorios con 
Podemos considerar que la Memoria de Carrasco sea el núcleo ideológico en el que se funda todo el proyecto de rehabilitación y reedificación que se llevó a cabo en los años inmediatamente posteriores. Debiendo destacarse en opinión nuestra las continuas referencias a que el edificio del Buen Retiro debía de presentarse como un conjunto homogéneo y, sobre todo, coherente más que con su propia historia con el nuevo entorno que le rodeaba, empezando por el Museo del Prado y su arquitectura. ${ }^{42}$

De esta manera y pese a algunas resistencias se procedió a realizar una serie de estudios sobre la posibilidad de adquirir algunas de los solares colindantes. Circunstancia refrendada en los planos de 1876 y en relativo informe de costes. Sin embargo, frente al planteamiento de expansión total del Museo por parte de Carrasco, en un primer momento, se procedió a través de

una puerta centras figurada, conservando el aspecto general que recuerda la época de la construcción. Por la parte opuesta se edificarán dos alas perpendiculares en los extremos, de la misma altura y construcción que el cuerpo principal, de la anchura que permita la fachada norte y longitud proporcionada para contener cada una en una planta principal un salón semejante al primero y al tercero a continuación de estos, pero a escuadra con ellos. Las alas se enlazarán por medio de una galería de planta baja paralela al cuerpo del edificio, dejando este y aquella un patio cerrado. Se completaría la fábrica con un para rayos en cada torre, un reló en una de ellas, y una fuente en el medio del patio. Reformas interiores- La distribución interior podría ser como sigue. Para la Exposición de objetos o verdadero Museo, además de los tres salones actuales, los dos que resultarán en las nuevas alas en la planta principal, y en la baja todo lo que coje de torre a torre; la comunicación entre ambas plantas por una escalera situada en el cuerpo avanzado de la nueva torre y la salida de la baja al portal, por donde ahora están la fragua y el taller de carpintería. La planta baja de las dos alas, para oficinas y otras dependencias necesarias; la galería que forma el cuarto lienzo del patio, para talleres: este patio para las experiencias y pruebas de armas y municiones; y las boardillas, sotabancos y otros espacios sobrantes para habitaciones de los empleados y dependientes. El decorado y disposición de los departamentos por lo respectivo a la fábrica, se entiende que ha de ser con el decoro correspondiente al objeto del establecimiento. Los salones de la planta principal, después de desaparecer las paredes que acortan el primero y tercero actualmente, tendrían las bóvedas adornadas por el estilo del de los Reinos, aunque con asuntos alusivos a los diferentes ramos del arte militar y del cuerpo artillería; sus pavimentos de losetas o mosaicos de colores, sus huecos de puertas y ventanas con la debida igualdad y simetría, señalados aquellos que no puedan serlos verdaderos a causa de la construcción. La planta baja sin más tabiques ni divisiones que las trasversales que absolutamente pidan las proporciones entre la longitud y la escasa altura, aunque con las precisas columnas para soportar la techumbre, su piso, con la firmeza y resistencia necesaria para resistir al peso y movimiento de los cañones, carruajes, proyectiles y maquinas que allí han de estar depositadas y moverse. Los huecos de luz, como abiertos a flor de tierra, deben de tener todos rejas iguales, con excepción de los centrales que serán puertas cocheras, para las entradas y salidas de dichos objetos de grandes dimensiones, para comunicar directa esta parte con el exterior y con el patio y para el mejor aspecto de las fachadas. Inmediaciones. En cuando al espacio circunvecino, claro está que deberá ser amplio y despejado, para dejar campear aislada y libremente el edificio, y para proporcionarle el declive que requieres su elevación sobre el nivel de las inmediatas calles y paseos. Este espacio se cerrará por su frente con una verja, a la cual servirá de portada el arco de piedra que está en los desmontes entre el Dos de Mayo y el Museo de Pinturas, construido en 1690, y que sirvió en otro tiempo de ingreso al Retiro bajo el nombre de puerta del Ángel, o la fama, circunstancia que le hace acreedor a salvarle de la ruina y del olvido, y muy propio para el lugar propuesto. El referido espacio, cerrado y adornado con jardín, y tal vez con algunas esculturas de persona u objetos, perteneciente a la carrera de las armas que es posible que existan ignoradas en alguna dependencia militar, o que con el tiempo se pudieran construir, reportaría otra ventaja sobre la de dar majestad al edificio y hermosura a un paraje que tan imperiosamente lo exige, por su situación rodeado de monumentos como el obelisco de la Independencia, el Museo de Pinturas, el Palacio de S. Juan y la no lejana puerta de Alcalá que, con el Prado, el Jardín Botánico y el Retiro, Parque de Madrid, pueden formar el paseo más delicioso de todas las cortes de Europa»; A. CARrasco y SAYz, Memoria Histórico descriptiva del Museo de Artillería escrita en 1874, op. cit., pp. 54-59.

42. P. Moleón Gavilanes, Proyecto y obras para el Museo del Prado. Fuentes documentales para su historia, Madrid, 1996, part. pp. 47-70. 
un proceso de desarrollo paulatino siguiendo un estricto orden de prioridad, conociéndose hacia mayo de 1876 por parte de la Junta Superior Facultativa el coste total de la obra de la planta baja. Por otro lado, aún en septiembre de 1877 no se habían cedido los terrenos circundantes al Buen Retiro, pareciendo cada vez más necesario proceder a aislar el Museo por la propia seguridad de los fondos. También por esta razón se esperaba que en el plan urbanístico del Ayuntamiento «las calles que le rodeen sean anchurosas y paralelas a sus fachadas las de las que a él den en frente» ${ }^{43}$ En este marco la operación más compleja en los elementos estructurales del edificio era la de comprobar su estado y resistencia, debido a su dificultad y a su coste. ${ }^{44}$

Solo un mes más tarde, por una Real Orden de 19 de abril de 1879, el proyecto expuesto en la Memoria de Carrasco lograba su objetivo, al disponerse que el cuerpo de Artillería pudiese hacerse cargo de las obras de conservación y restauración que considerase necesarias en el edificio del Buen Retiro, por ser sede del Museo y «por el interés histórico de la conservación de la parte que aún existe del antiguo Palacio y Corte del Buen Retiro». ${ }^{45} \mathrm{Al}$ cabo del año siguiente se presentó el proyecto de reforma recogido en los planos de Casimiro Lanaja y se presupuestó la misma [Fig. 12]. La comparación entre este proyecto de reforma ${ }^{46} \mathrm{y}$ el estado actual de las fachadas ${ }^{47}$ [Fig.14] y de los interiores, por lo menos en la salas principales, confirman que se llevó a cabo en la amplia mayoría de sus elementos esenciales y nos ofrece preciosas indicaciones sobre los materiales utilizados y las características de las intervenciones [Fig. 13]. Posteriormente se levantó un piso en la zona de las buhardillas y se modificaron los volúmenes de la fachada sur al añadir dos cuerpos laterales y unas cristaleras cuya finalidad era la de ampliar las zonas expositivas ${ }^{48}$ quedando de hecho desvirtuada la naturaleza del proyecto de 1880 dejando el Museo en un estado muy cercano al actual. ${ }^{49}$

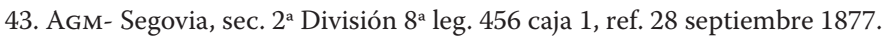

44. «descubrir en varias partes las maderas que las formaban, así como las carreras y muros que los sostienen, pero he de ocasiona algunos gastos en hacer y levantar guarnecidos y cielos-rasos, forjados y pavimentos, volviéndolos a reponer de la manera que estaban» AGM- Segovia, sec. 2a División $8^{\text {a }}$ leg. 456 caja 1, ref. 28 marzo 1579

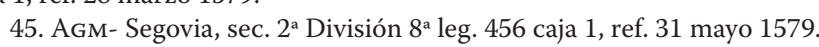

46. Véase anexo 29, cf. C. Lanaja y Mainar, Obras del Museo de Artillería, Madrid 1891.

47. AgM- Segovia, sec. $2^{\text {a }}$ División $8^{\text {a }}$ leg. 456 caja 1, ref. 31 mayo 1880 y anexo 30.

48. Del Parque de Monteleón al Palacio del Buen Retiro. Un legado para el futuro, Cat. Exp. (C. García Campa, M. ${ }^{\text {a }}$ J. Rubio Viseras coms.), Madrid 2003, p.11.

49. Guía del Museo del Ejército, Madrid 1984, pp. 13-14. 


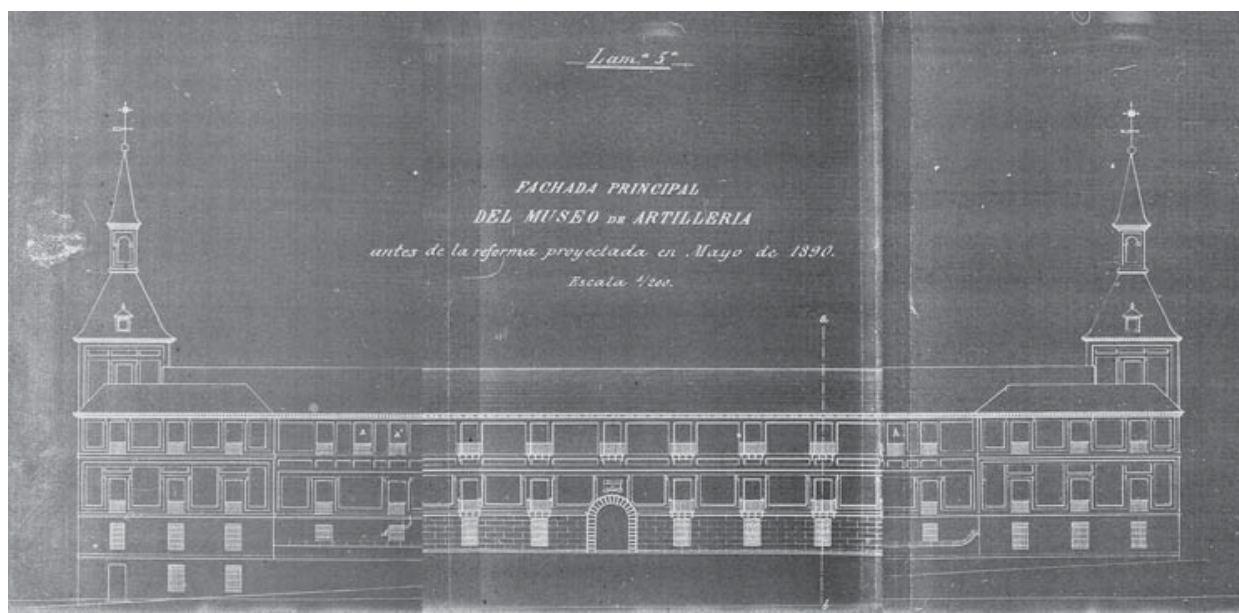

Fig. 12. Dibujo del proyecto de reforma que acompañaba la Memoria de A. Carrasco y Sayz, 1874-1876
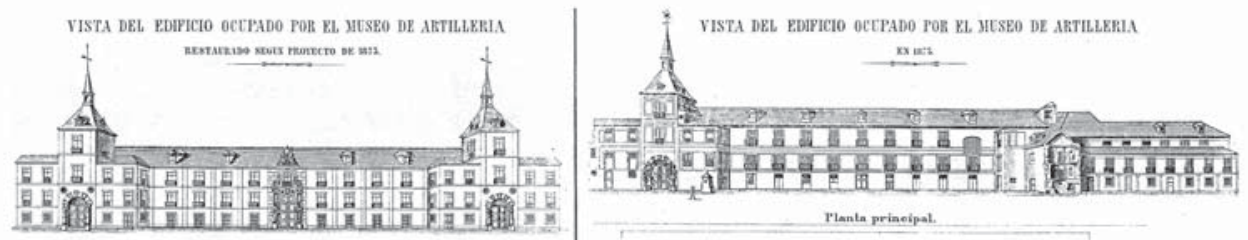

Planta prineipal.

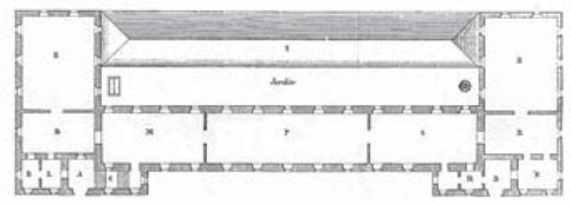

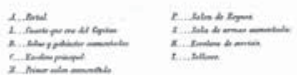

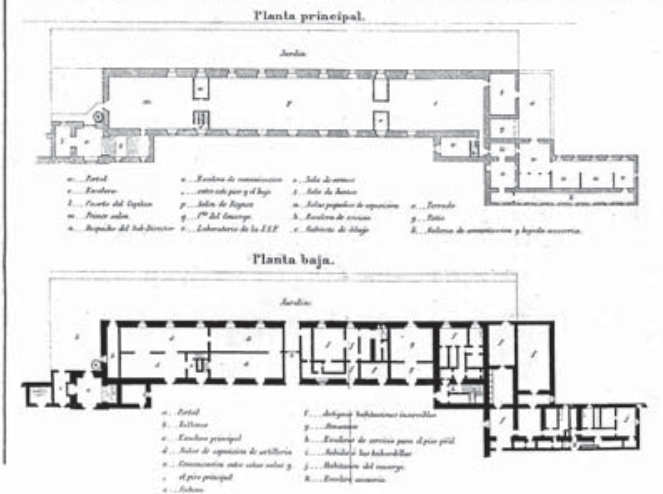

Fig. 13. Croquis de los terrenos en que se halla el edificio ocupado por el Museo de Artillería, superficie de los mismos que se propone aumentar e indicación de la que debe edificarse para que dicho museo llene las condiciones de destino, 1876; AGM- Segovia, sec. $2^{\text {a }}$ División $8^{\text {a }}$ leg. 456 


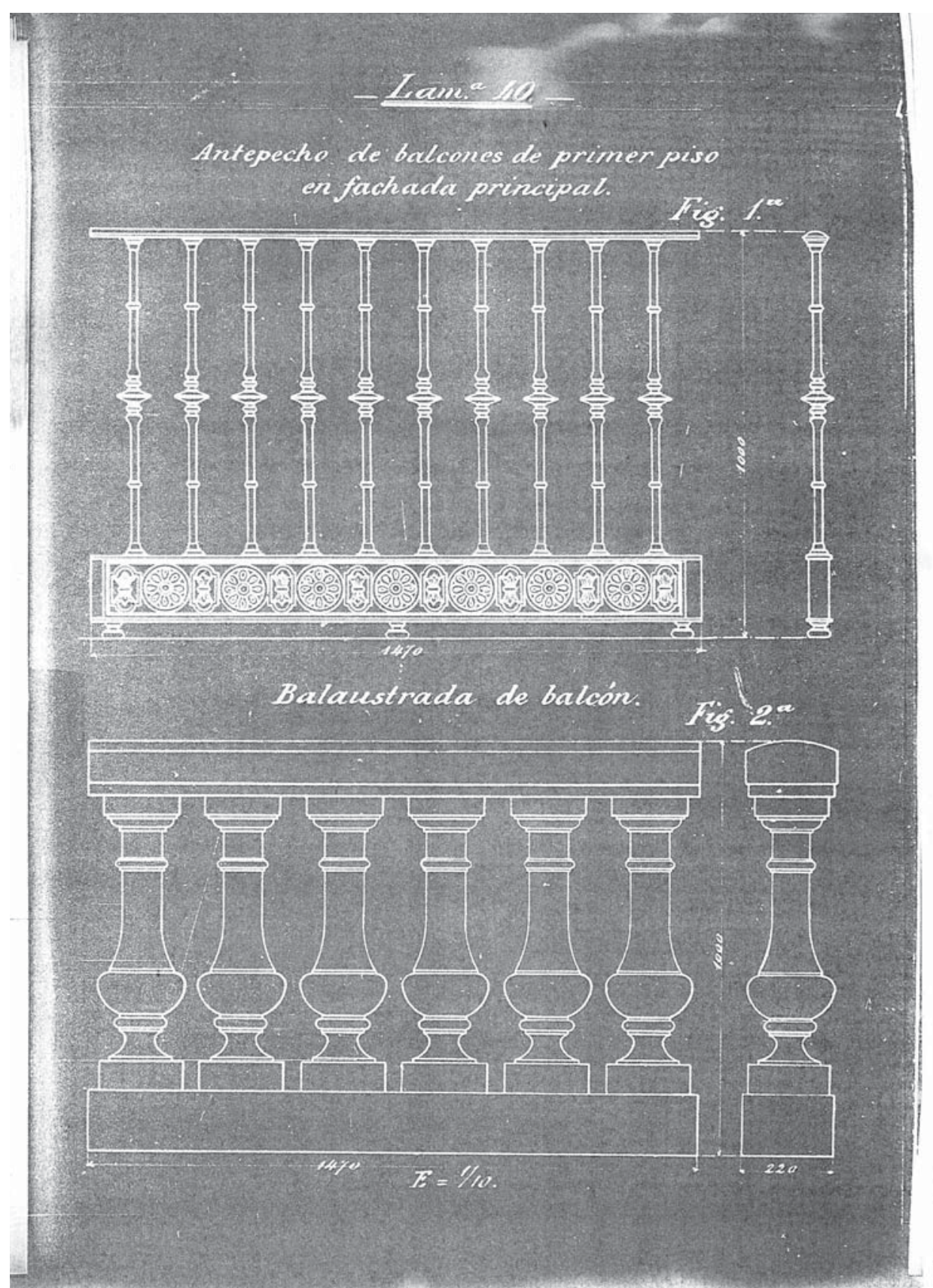

Fig. 14. Detalle, lámina 40 